\title{
Indian Mughal Turban BoXes As Cultural Indicators Civilizational AND ARTISTIC STUdY
}

BY

\section{Hamada Thabet Mahmoud}

Associate Professor of Islamic Archaeology Dept., Faculty of Archaeology, Fayoum University.

\begin{abstract}
Applied arts, e.g. turban boxes, in the era of Mughal Indian emperors express the Mughal's civilization and creativity. This paper is an artistic study of these boxes, as well as the name and its relation to fulfilling the function of the boxes. Mughals in India whether emperors or princes, paid considerable attention to turbans, as shown in having turban boxes. These turbans were decorated with gemstones and precious jewelry. Moreover, there were various patterns of turban boxes at the time. Some boxes had an onion-dome cover, semicircular covers, or polygons. The environment affected the decorations of these boxes considerably because they were largely related to the culture of the Indian regions that produced them, including deities, animals, mysterious creatures, as well as floral and geometric motifs. The present research paper aims to examine the materials used in manufacturing such turban boxes, as wood and papier-mâché that were processed to fit the function of the boxes and not to harm the precious contents. It showed that the general design of the turban boxes was affected largely by architectural constructions, e.g., the impact of contemporary Mughal Indian architecture.
\end{abstract}

KEYWORDS: Box, Turban, Wood, Papier-mâché, Mughal, Indian, Arts, Portrait, Enamel 


\section{INTRODUCTION}

In the Mughal Indian era (932-1273AH/1526-1857AD), applied arts were the most important industry because they received due attention from the Mughal emperors and princes and Muslim princes in different regions. Therefore, several applied arts, including turban boxes appeared. The interest of Mughals in headgears, in general, and turbans, in particular, is an important issue in their culture. However, these boxes were not familiar with the previous cultures and arts in India. Turban boxes were used for the high material and moral value of the turbans and the precious gems they contain.

\section{NOMINATIONS AND CONNOTATIONS}

The term juaba distar, i.e., a turban box, is Persian. It consists of two parts the first part is «juaba», i.e., a small box for keeping important things, including the turban and accessories, e.g., the diamond of the turban ${ }^{1}$, whereas the second part «distar», i.e., turban², pl. turbans known as crowns of the Arabs ${ }^{3}$. It is a cloth encircling the head or coming down on the shoulder ${ }^{4}$. Desert life was one of the factors that motivated the Arabs to have turbans. Thus, a turban is called Pargi ${ }^{5}$ in Urdu. For the Mughals, a turban is a large piece of cloth folded over the head with an embroidered piece of cloth hanging down'.

\section{Philosophy OF Using Turban BoXes}

In general, a turban has many benefits for the Muslim communities, such as protecting them from heat, rain, or events. It also increased the stature ${ }^{7}$. The Arabs and the peoples of the East used turbans since immemorial time, as shown in the paintings of the Arab School. Moreover, it was ranked first in the headgears of rulers in the early Islamic times, and people spent a lot of money on it. Furthermore, it was a kind of societal discrimination. For instance, the turbans of the rulers were made of the most expensive kinds of fabrics, such as brocade and silk and were sometimes adorned with gemstones and jewelry ${ }^{8}$. Because of its prominent place over the various Islamic eras, taking it off in front of people decreased the position and decency of the man. It was not allowed to be taken off in courts ${ }^{9}$. Additionally, the Caliphs deliver speeches while wearing turbans ${ }^{10}$.

Turbans were transferred to the Indians from the Arabs. al-Bīrūni reported that «they (the Indians) used to wear turbans» ${ }^{11}$. The rulers and princes of the Mughals paid due attention to the turban and used boxes for them. In other words, turbans were not used

\footnotetext{
${ }^{1}$ KASRATY 2014: 170.

2 POOJA 2016: 12.

3 IBRAHIM 2002: 334.

4 RASHEED 1980: 36.

${ }^{5}$ RENHAR 1971:160.

6 POOJA 2016: 12.

7 AL-JAHIZ 1998:117.

${ }^{8}$ GOITEN 1983:158.

9 IBRAHIM 2007: 72.

10 IBRAHIM 2007: 72.

11 EL-BĪRŪNī 1990: 89.
} 


\section{Hamada Thabet Mahmoud}

as headgears only, but they symbolized dignity and pride and were made of expensive textiles, especially for senior statesmen ${ }^{12}$. In his memoirs, Babur (932-937AH/1526$1530 \mathrm{AD}$ ) reported that the members of a social class should wear a distinguished form of turbans. A turban consisted of a multi-fold piece of cloth decorated sometimes with gemstones and feathers. At the time of Babur, a turban had up to 17 folds $^{13}$. At the time of Hamayun (937-946AH/1530-1539AD) and (962-963AH/1555-1556AD), the turban had a new function. Hamayun reported in his memories that the turban was used in climbing high places because men tie turbans together and used them for climbing ${ }^{(14)}$. Greater interest was shown in the era of Akbar (963-1014AH/1556- 1605 AD) when turban makers enjoyed several benefits and supervision by statesmen, and wearing a turban was an official practice ${ }^{15}$. In the era of Jahangir (1014-1037AH/ 1605-1628AD), the turban was adorned with jewelry and gemstones, as reported by the French traveler Francois Bernier ${ }^{16}$. At the time, children also wore turbans especially the sons of princes and the wealthy ${ }^{17}$. In the era of Aurangzeb (1086-1108AH/1658-1707AD), the turbans of princes were rich in gemstones and became the official habit for all state rulers in India $^{18}$. Gemstones used for turbans took the form of leaves fixed using a stick of expensive materials that was straight in the time of Akbar and a bit low in the time of Jahangir ${ }^{19}$. Gold was sometimes used in the stick topped by gemstones. Moreover, the feather was sometimes made of gold or gemstones. Furthermore, the jewel used in the stick was called sarpech ${ }^{20}$. The excessive use of gemstones in the feather and stick was the cause of using small boxes styled after the turban boxes for keeping these stones. The pictures of manuscripts showed the high value of the Indian turban and using gemstones for decoration. For instance, the rulers and princes of the Mughal state wore turbans decorated with gemstones entirely, including the stick and the feather. [FIGURE 1]

\footnotetext{
12 POOJA 2016: 16.

${ }^{13}$ KAMADA 2011: 48.

14 SHARMA 1934: 96.

15 JACKSON 1906: 123.

16 POOJA 2016: 16.

17 OTTO-KURZ 1967: 254.

18 JAFFAR 1936: 324.

${ }^{19}$ MICHEL 2007: 212.

20 SWARUP 1996: 80.
} 


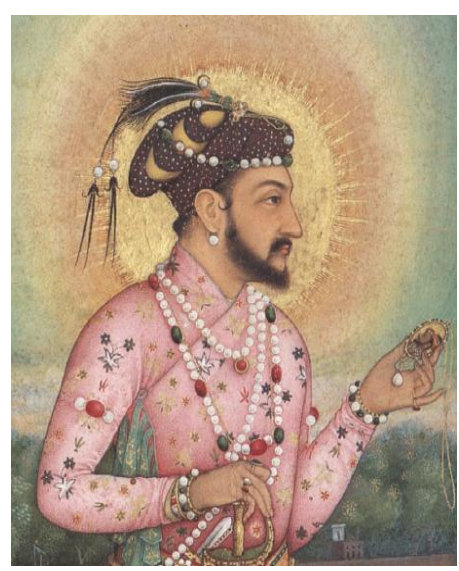

A: Portrait of Shah Jahan showing a turban studded with precious stones. KOSSAK 1997: FIG.6.

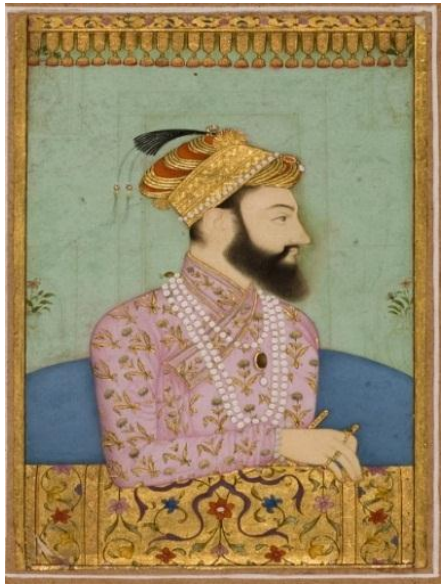

B: Portrait of Aurangzeb showing a turban studded with precious. Eskenazi Museum of Art, Indiana University.

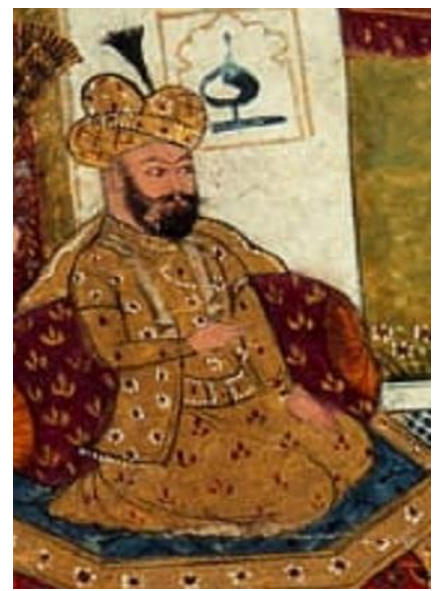

C: Painting of One of the princes of Kashmir showing a turban studded with precious. Mūt'a alnisa' Manuscript, $18^{\text {th }} \mathrm{AD}$, cABD AL-RAHIM 2010: P.26.

[FIGURE 1]: portraits of the Mughal emperors, wearing turbans adorned with precious.

\section{ARtistic StYles}

The general style of turban boxes comprised two main parts: The lower (body) and the upper (cover/ top) parts. There are several Styles.

The $\mathbf{1}^{\text {nd }}$ style: This style comprised a circular body and a semi-spherical dome. The body was decorated with various decorative themes. For instance, a wooden box dating back to the $18^{\text {th }}$ century kept at the National Crafts Museum in India is $26.1 \mathrm{~cm}$ high and $38.1 \mathrm{~cm}$ in diameter. The body was decorated with two-level pictorial scenes, including Indian celebrations and knights on horses. Furthermore, Krishna idol was painted in the upper part of the cover, performing the «Rasmandela» dance with cow milkers, [FIGURE 2]. Another example of this style was made of papier-mâché in Kashmir dating back to the $19^{\text {th }}$ century at the National Museum in Delhi. It is $25 \mathrm{~cm}$ in diameter and $15 \mathrm{~cm}$ high. The body and covered with local decorations of Indian deities, such as Shiva, Hanuman ${ }^{21}$, Nandy, horses, and lovers, [FIGURE 3].

${ }^{21}$ Shiva is the god of destruction and cruelty. It is the embodiment of a universal power that destroys all figures in which the universal reality appears, although Shiva literally means "the kind". 


\section{Hamada Thabet Mahmoud}

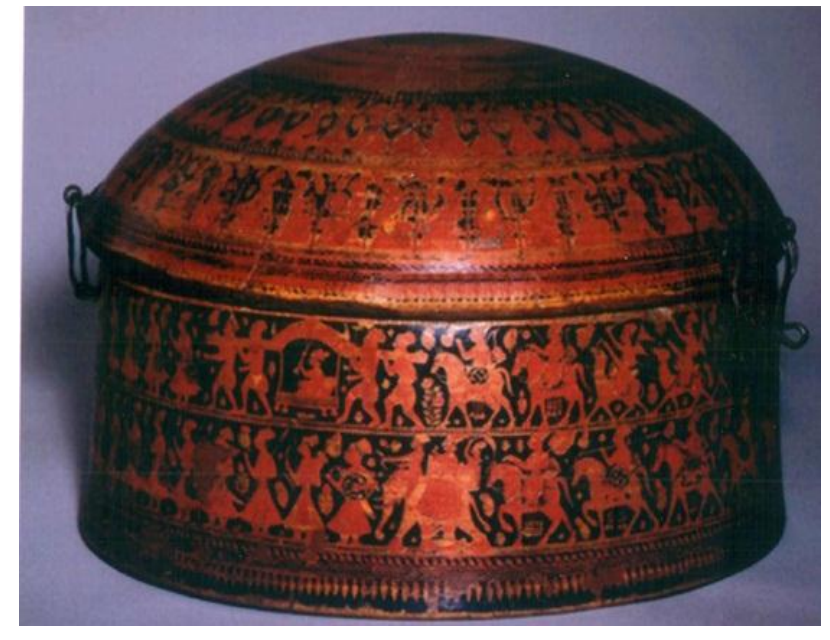

[FIGURE 2]: Turban box, wood, $18^{\text {th }}$ century, Museum of Handicrafts in India.

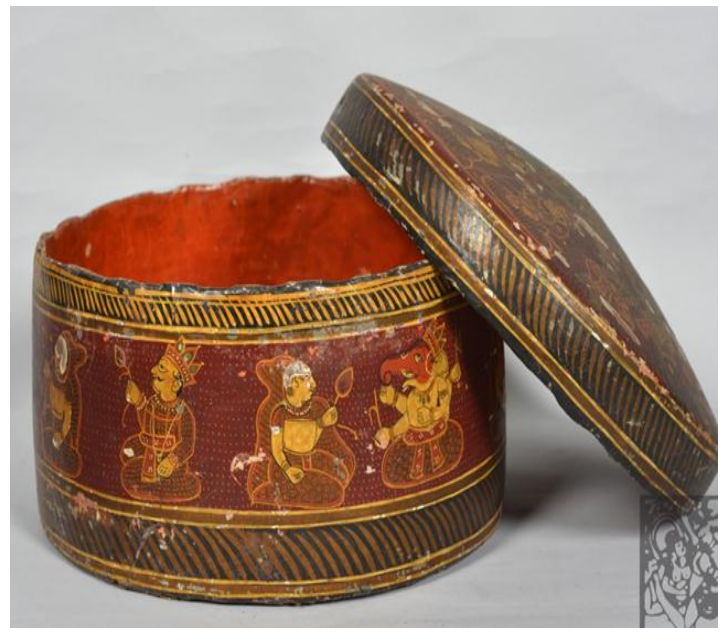

[FIGURE 3]: Turban box, papier-mâché, 19 century ،The National Museum of Delhi.

The $2^{\text {nd }}$ style: It consists of a circular body and an onion-like dome cover. For example, a wooden style in Kashmir was made in the $19^{\text {th }}$ century kept in a private collection. It resembles the former style, except for the onion-like dome. It is decorated with geometric strips encircling the body and including medallions containing different floral motifs of flowers and branches. The cover has the same decorations, [FIGURE 4]. Another box of wood painted with Lacquer of the $1^{\text {th }}$ century in Kashmir. It is $14 \mathrm{~cm}$ high and $22 \mathrm{~cm}$ in diameter kept at the collection of John Nicholsons Fine Art Valuer. It is quite similar to the previous box. It has floral motifs of flowers and branches including bird figures, [FIGURE 5].

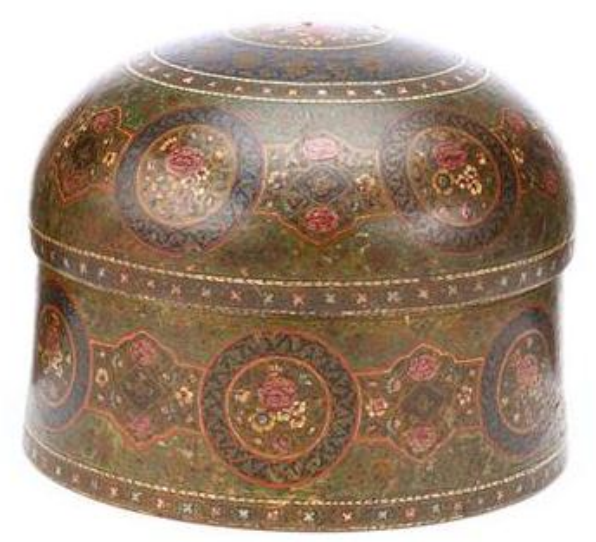

[FIGURE 4]: Turban box, wood, $19^{\text {th }}$ century ،the collection of John Nicholsons Fine Art Valuer.

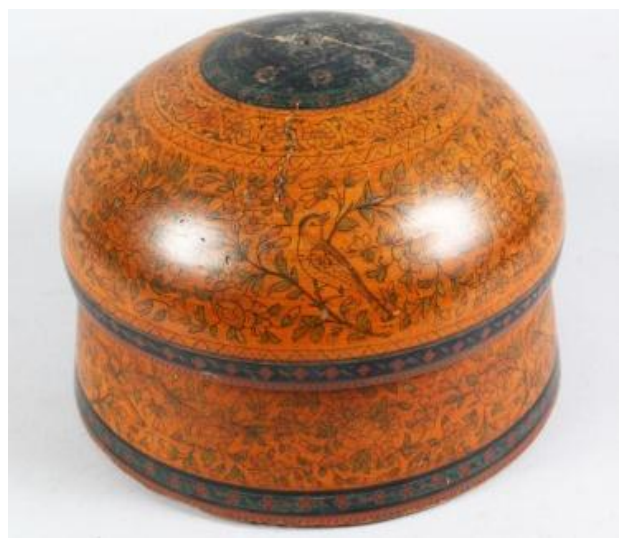

[FIGURE 5]: Turban box, wood, $1^{\text {th }}$ century ، the collection of John Nicholsons Fine Art Valuer.

The $3^{\text {nd }}$ style: This style resembles the previous one except for the circular body (thin in the bottom and wide at the top) and the cover that takes the form of a convex dome. For example, a box was made of papier-mâché in Kashmir in the $18^{\text {th }}$ century. It is kept in a 
private collection of wjm (Will Jon Mattin ${ }^{22}$ ) antiques. It is based on a circular base and covered with a convex dome. It is $16.1 \mathrm{~cm}, 21.3 \mathrm{~cm}$ in diameter, and $686 \mathrm{gm}$ weight. The body and the cover are decorated with overlapping branches and flowers, such as a carnation flower in geometric configurations, [FIGURE 6]. Another box of papiermâché dating back to the $18^{\text {th }}$ century is kept at the Richard Willsher Antique Asian Art. It is $16 \mathrm{~cm}$ high and $21 \mathrm{~cm}$ in diameter. The body is decorated with scenes of a prince on a throne, a woman playing music on a string instrument, and Rustam killing the dragon. The top part of the cover was decorated with scenes of princes and princesses in dancing concerts, [FIGURE 7].

A box of papier-mâché dating back to the $18^{\text {th }}$ century in Kashmir is kept at a private collection. It is $16 \mathrm{~cm}$ high and $26 \mathrm{~cm}$ in diameter. It follows the same design, but the body is decorated with scenes of knights on horses, and the cover is decorated with knights and princes in royal settings, as well as scenes of ladies, [FIGURE 8].

A box of papier-mâché dating back to the $19^{\text {th }}$ century is kept at the Victoria and Albert Museum in London. Its body is decorated with pictorial scenes of a princess and her maids in a garden surrounded by various floral motifs, whereas the cover is decorated with flowers and birds, [FIGURE 9]. At the same museum, there is another similar box but decorated differently. It is divided into horizontal sections starting from the base to the top part of the cover. Each geometric configuration has a decoration theme, such as a princess sitting on the throne surrounded by her maids playing musical instruments and angels above. The other configurations include floral decorations of trees from which branches emerge and end with different flowers, including carnation. Moreover, birds are on the branches, [FIGURE 10].

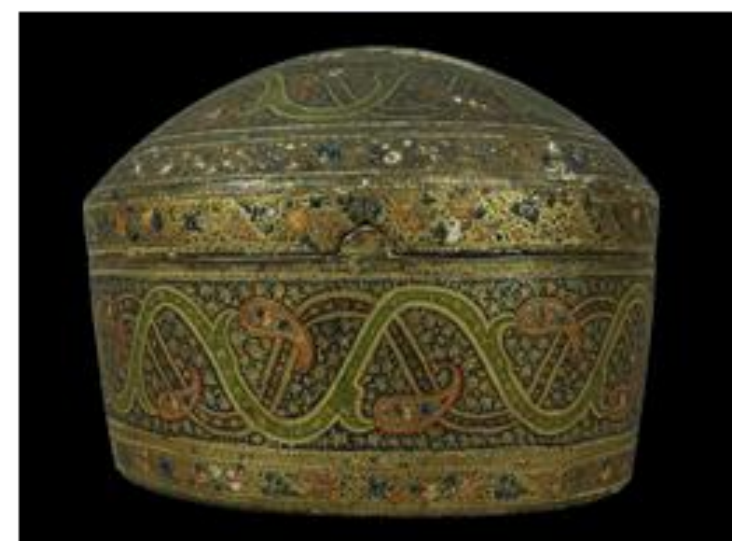

[FIGURE 6]: Turban box, papier-mâché, $18^{\text {th }}$ century, Kashmir, the collection of wjm (Will Jon Mattin) antiques.

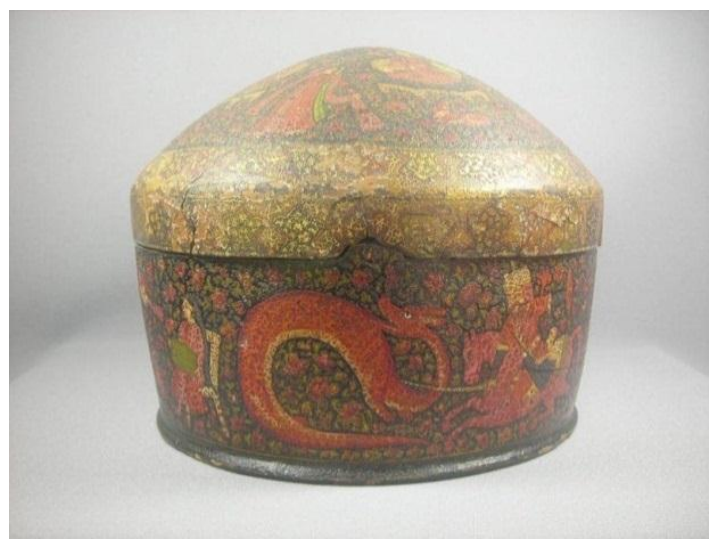

[FIGURE 7]: Turban box, papier-mâché, $18^{\text {th }}$ century, Kashmir, Richard Willsher Antique Asian Art.

${ }^{22}$ It is a private collection for the master Will Jon. It displays collections of Asian artifacts that chosen for the website are generally sourced from within the UK art \& antiques market, also private collections 


\section{Hamada Thabet Mahmoud}

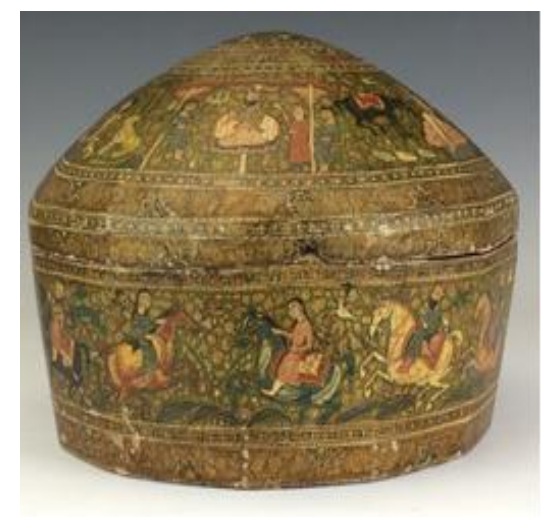

[FIGURE 8]: Turban box, papier-mâché, 19 century, the collection of wjm (Will Jon Mattin) antiques.

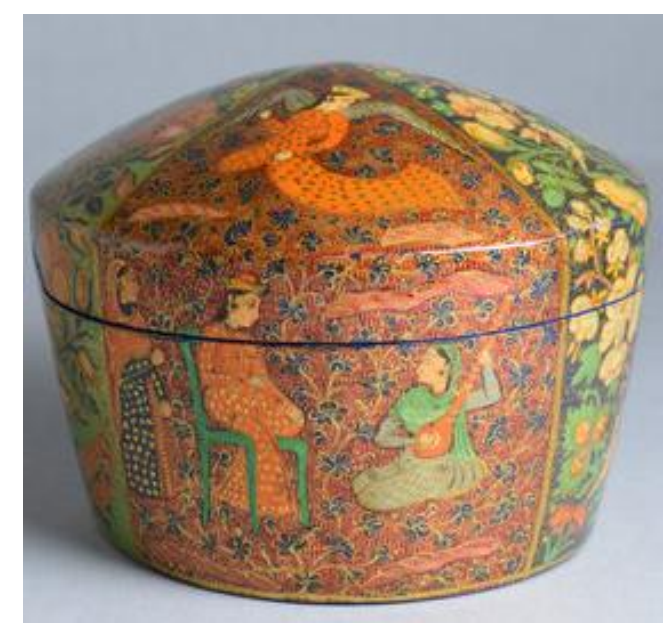

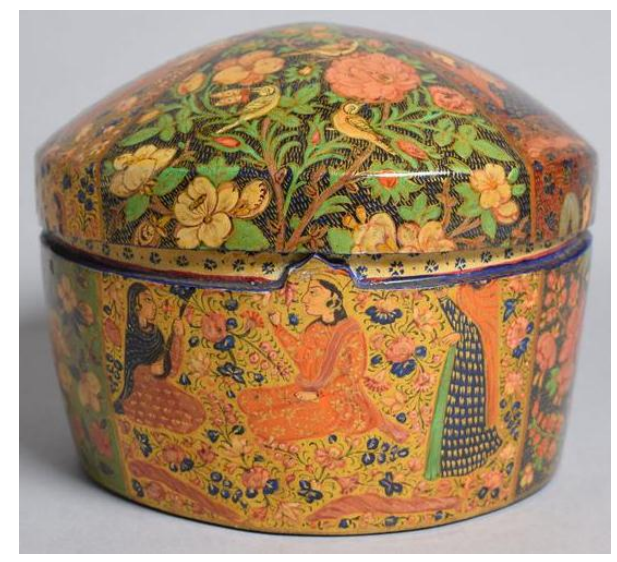

[FIGURE 9]: Turban box, papier-mâché, 19 ${ }^{\text {th }}$ century, Victoria and Albert Museum.

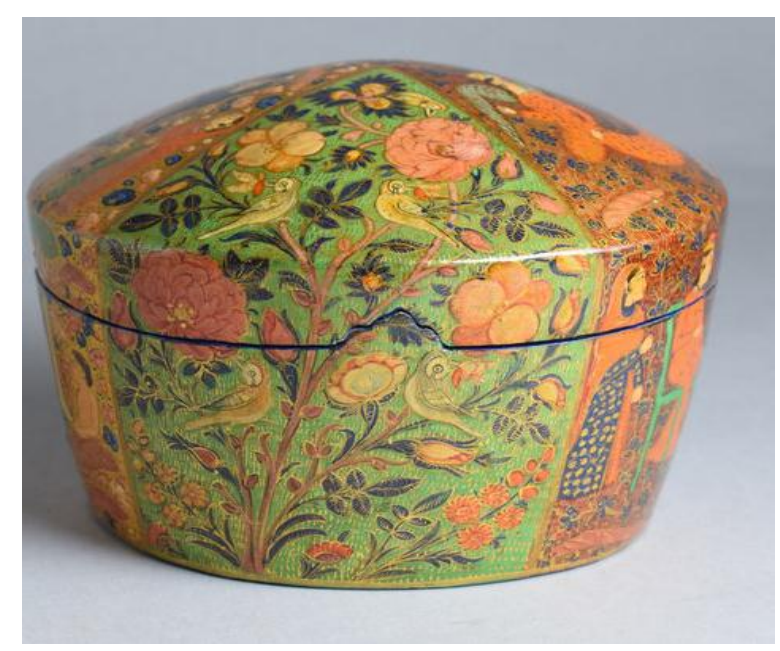

B: Side of box.

A: Side of box.

[FIGURE 10]: Turban box, papier-mâché, 19 ${ }^{\text {th }}$ century, Victoria and Albert Museum.

The $4^{\text {nd }}$ style: It is a polygon or a decagon. The body is a decagon, and the cover is a polygon dome based on the edge of the body through a polygonal tip. For example, a wooden box was made in Kashmir in the $19^{\text {th }}$ century kept in a private collection (Windhorse antiques ${ }^{23}$ ). It is $19 \mathrm{~cm}$ high, $26 \mathrm{~cm}$ in diameter, and 900gm weight. The body and the cover are decorated with floral motifs and flowers on a floral ground inside geometric divisions caused by the ten sides. From inside, the sides are decorated with medallions filled with floral motifs, whereas the ground contains a star figure with geometric decorations. The cover is decorated from inside with a star surrounded by almond-shaped flowers interchanged with cypress trees, [FIGURE 11].

The $5^{\text {nd }}$ style: It is an octagon. For instance, a box made of papier-mâché in Kashmir in the $19^{\text {th }}$ century is kept at the Victoria and Albert Museum in London. It consists of an octagonal body and an octagonal dome decorated with configurations of Indian

${ }^{23}$ Its private collection based in London \& France, Windhorse Antiques has over 40 years of experience in the Antiques trade. Laura \& Philip Trent, long time Indophile travellers, have also lived in India for many years. 
flowers, such as roses and carnations flowers, [FIGURE 12]. Another box kept at the Saleroom.com of art antiquities measures $15 \mathrm{~cm}$ high and $22 \mathrm{~cm}$ in diameter. It is decorated with palmettes in a zigzag covering the entire body. The cover is decorated with palmettes in a polygon, whereas the segments are decorated with Bukhariat, [FIGURE 13]. A third box made of papier-mâché in Kashmir in the $19^{\text {th }}$ century is kept at Curious Antiques. It is $14 \mathrm{~cm}$ high and $23.5 \mathrm{~cm}$ in diameter. Each side of the polygon is decorated with a scene of princes on their horses, others on elephants, and women playing musical instruments, [FIGURE 14]. A fourth example made of papier-mâché in Kashmir in the $19^{\text {th }}$ century is kept in the private collection of Rob Michiels. It measures $18 \mathrm{~cm}$ in diameter and $15 \mathrm{~cm}$ high. It is decorated with various scenes of knights on their horses, angels, as well as princes and princesses in the open air. [FIGURE 15]

Some small paper boxes of this style were almost used for keeping the precious accessories of the turban, such as the jewel in the middle of the turban. For example, a box made of papier-mâché in Kashmir in the $19^{\text {th }}$ century is kept at the Indian Museum in Calcutta. It measures $5 \mathrm{~cm}$ high and $7.3 \mathrm{~cm}$ in diameter. It has an octagonal body and a polygonal neck. The body is decorated with scenes on every side of men, women, and Indian deities. The neck is decorated with scenes of animals, including snakes, foxes, and birds, whereas the cover contains figures of the Indian heritage, [FIGURE 16]. Another box made in Kashmir in the $19^{\text {th }}$ century is kept at the Indian Museum in Calcutta. It measures $3.5 \mathrm{~cm}$ high and $5.5 \mathrm{~cm}$ in diameter. It has the same previous design and is decorated with figures of the Indian heritage, as well as birds and animals, [FIGURE 17].

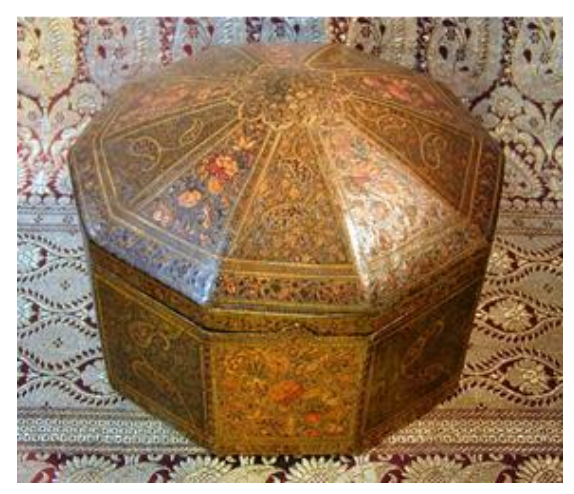

A

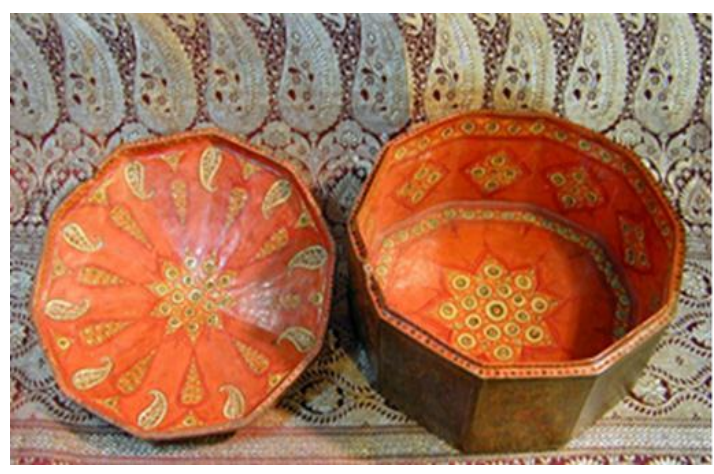

B

[FIGURE 11]: Turban box, wood, Kashmir, 19th century, collection of Windhorse antiques. 


\section{Hamada Thabet Mahmoud}

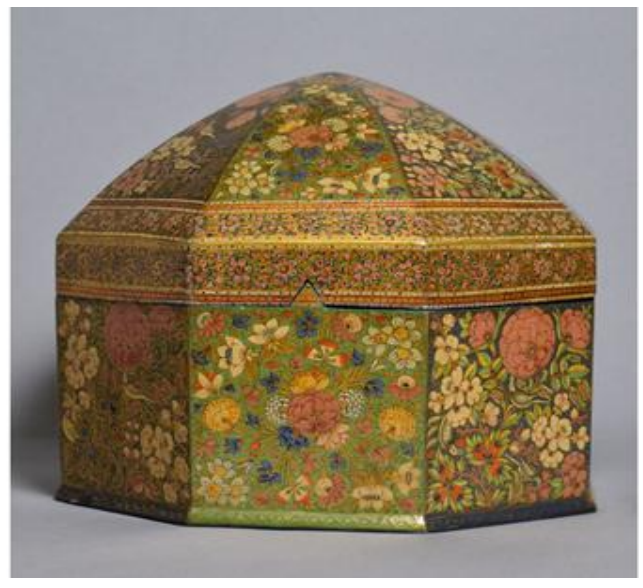

[FIGURE 12]: Turban box, papier-mâché, Kashmir, 19 ${ }^{\text {th }}$ century, Victoria and Albert Museum.

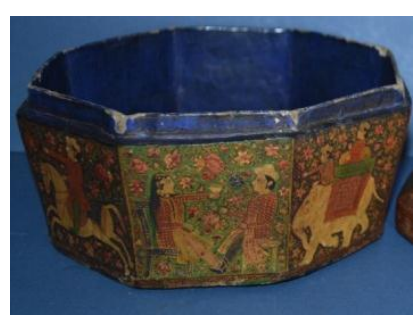

A

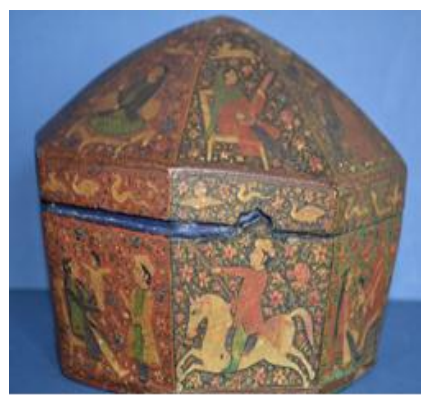

B

[FIGURE 14]: Turban box, papier-mâché, Kashmir, 19 century, collection of Curious Antiques.

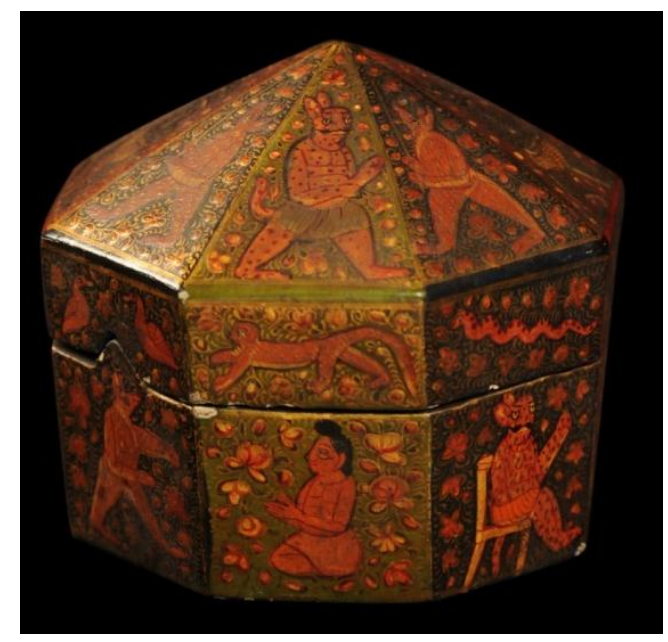

[FIGURE 16]: Turban box, papier-mâché, Kashmir, ${ }^{19}$ th century, Calcutta Museum.

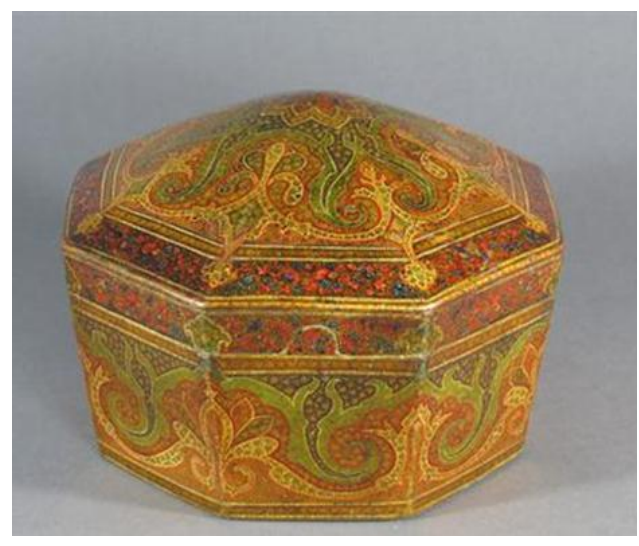

[FIGURE 13]: Turban box, papier-mâché, Kashmir, 19 ${ }^{\text {th }}$ century, collection of The-saleroom.com of art antiquities

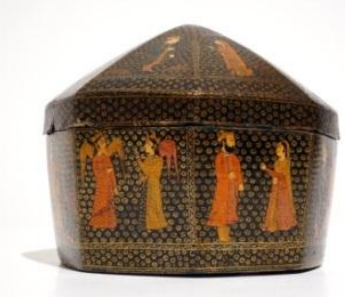

A

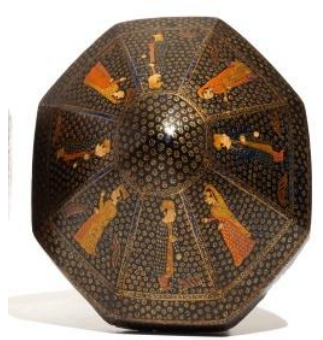

B
[FIGURE 15]: Turban box, papier-mâché, Kashmir, 19 ${ }^{\text {th }}$ century, collection of Rob Michiels.

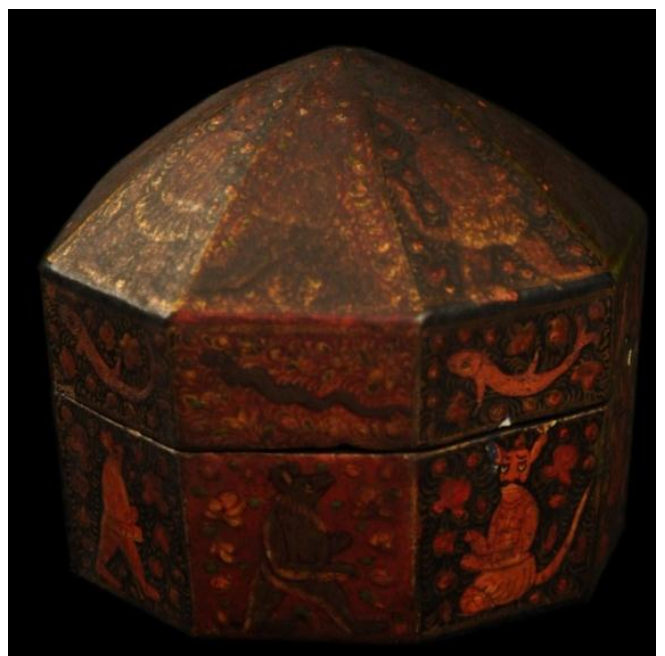

[FIGURE 17]: Turban box, papier-mâché, Kashmir, ${ }^{19}$ th century, Calcutta Museum. 


\section{Dimensions OF THE BOXES AND THEIR FunCtiOnAl RELEVANCE}

These boxes were made for a certain function, i.e., keeping turbans. Therefore, their design fits the function. The body: The body was designed in a manner that allows keeping the turban. Thus, the inner part was circular and wide in the circular boxes, and the polygon ones were treated to have a circular form inside, [FIGURES 2, 11]. The body measures $15-16 \mathrm{~cm}$ and $21 \mathrm{~cm}$ in diameter to allow keeping the turbans that had similar dimensions in the Mughal era; $13 \mathrm{~cm}$ high without the jewel and $19-21 \mathrm{~cm}$ in diameter. Moreover, the turbans had three folds and more ${ }^{24}$ to fit the function of the boxes. [FIGURE 18]

Top cover: The top cover was fixed on the box through a tip [FIGURES $6, \mathbf{7 , 1 1}$ ] The top cover was made as a movable separate part. It measured $5 \mathrm{~cm}$ to complete the box height to cover the turban entirely. It was hollow inside to ensure no friction with the precious top parts of the turban. [TABLE 1]

The small boxes used for storing the jewel fulfilled their function. While the jewel was $4 \mathrm{~cm}$ high, the box was about $5 \mathrm{~cm}$ high. [FIGURE 19]

\begin{tabular}{|c|c|c|c|}
\hline Box Height without Cover & $\begin{array}{l}\text { Height of the } \\
\text { Turban }\end{array}$ & Height of the Box & $\begin{array}{l}\text { Height of the } \\
\text { Turban and } \\
\text { Accessories }\end{array}$ \\
\hline $\begin{array}{l}\text { First Style: It was of an } \\
\text { average height of } 21 \mathrm{~cm} \text { and } \\
25 \mathrm{~cm} \text { in diameter. }\end{array}$ & \multirow{5}{*}{$\begin{array}{l}\text { The average } \\
\text { height of the } \\
\text { turban without } \\
\text { the jewel was } \\
13 \mathrm{~cm} \text { and } 19 \mathrm{~cm} \text { in } \\
\text { diameter. }\end{array}$} & $\begin{array}{l}\text { The box and the cover } \\
\text { measured } 26 \mathrm{~cm} \text { high and } \\
35 \mathrm{~cm} \text { in diameter. }\end{array}$ & \multirow{5}{*}{$\begin{array}{l}\text { The turban and the } \\
\text { jewel measured } 18 \mathrm{~cm} \\
\text { high. }\end{array}$} \\
\hline $\begin{array}{l}\text { Second Style: It was of an } \\
\text { average height of } 24 \mathrm{~cm} \text { and } \\
22 \mathrm{~cm} \text { in diameter. }\end{array}$ & & $\begin{array}{l}\text { It was of an average height } \\
\text { of } 19 \mathrm{~cm} \text { and } 29 \mathrm{~cm} \text { in } \\
\text { diameter. }\end{array}$ & \\
\hline $\begin{array}{l}\text { Third Style: It was of an } \\
\text { average height of } 16 \mathrm{~cm} \text { and } \\
21 \mathrm{~cm} \text { in diameter. }\end{array}$ & & $\begin{array}{l}\text { It was of an average height } \\
\text { of } 21 \mathrm{~cm} \text { and } 27 \mathrm{~cm} \text { in } \\
\text { diameter. }\end{array}$ & \\
\hline $\begin{array}{l}\text { Fourth Style: It was of an } \\
\text { average height of } 19 \mathrm{~cm} \text { and } \\
26 \mathrm{~cm} \text { in diameter. }\end{array}$ & & $\begin{array}{l}\text { It was of an average height } \\
\text { of } 24 \mathrm{~cm} \text { and } 27 \mathrm{~cm} \text { in } \\
\text { diameter. }\end{array}$ & \\
\hline $\begin{array}{l}\text { Fifth Style: It was of an } \\
\text { average height of } 16 \mathrm{~cm} \text { and } \\
22 \mathrm{~cm} \text { in diameter. }\end{array}$ & & $\begin{array}{l}\text { It was of an average height } \\
\text { of } 21 \mathrm{~cm} \text { and } 29 \mathrm{~cm} \text { in } \\
\text { diameter. }\end{array}$ & \\
\hline $\begin{array}{l}\text { The boxes measured } 14- \\
21 \mathrm{~cm} \text { high and } 21-26 \mathrm{~cm} \text { in } \\
\text { diameter. }\end{array}$ & $\begin{array}{l}\text { The average } \\
\text { height of the } \\
\text { turban without } \\
\text { the jewel was } \\
13 \mathrm{~cm} \text { and } 19 \mathrm{~cm} \text { in } \\
\text { diameter. }\end{array}$ & $\begin{array}{l}\text { The box and the cover } \\
\text { measured } 19-26 \mathrm{~cm} \text { high } \\
\text { and } 27-35 \mathrm{~cm} \text { in diameter. }\end{array}$ & $\begin{array}{l}\text { The turban and the } \\
\text { jewel measured } 18 \mathrm{~cm} \\
\text { high. }\end{array}$ \\
\hline
\end{tabular}




\section{Hamada Thabet Mahmoud}

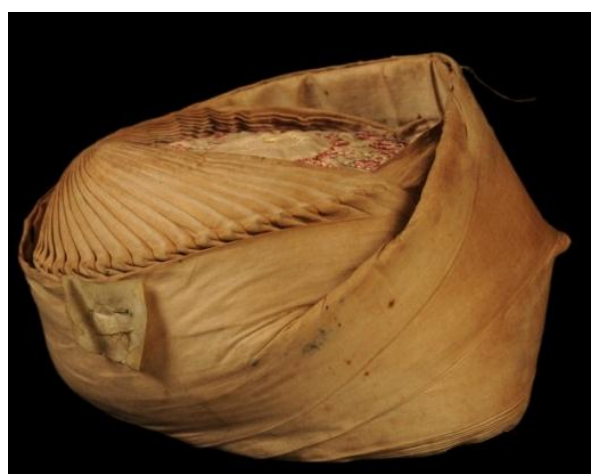

A: Cotton turban, Mughal India, 19 ${ }^{\text {th }}$ century, Calcutta Museum.
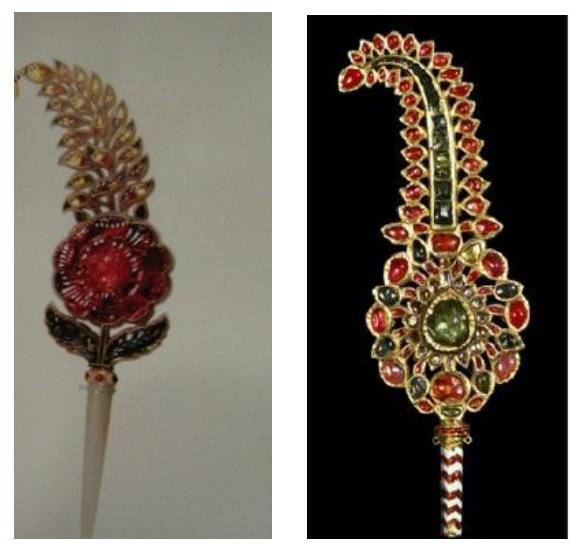

B: Precious stones that adorn the turban, Mughal India, MICHELL 2007: PL.212, 229.

[FIGURE 18]: The turban and the precious stones adorning it from Mughal India

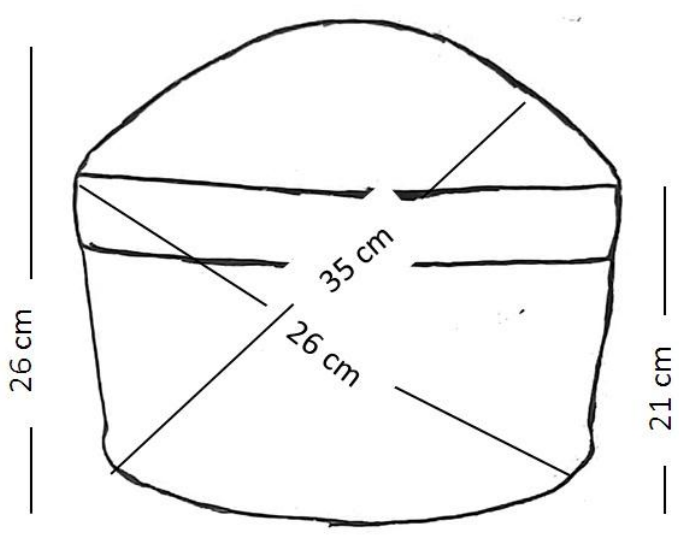

A: Turban box dimensions

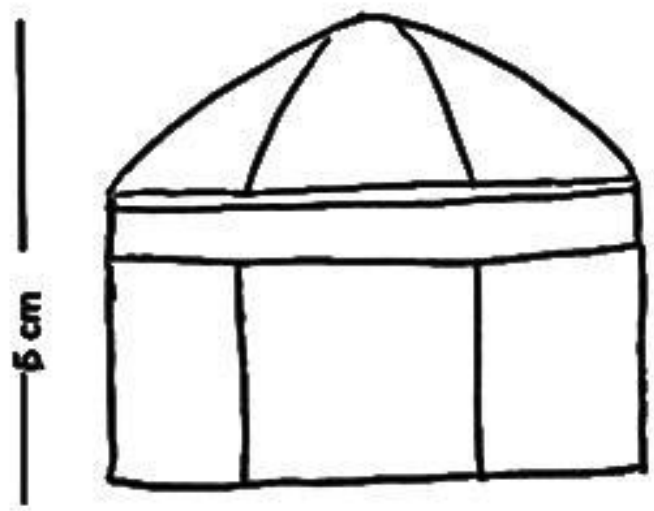

C: Box OF Precious stones dimensions

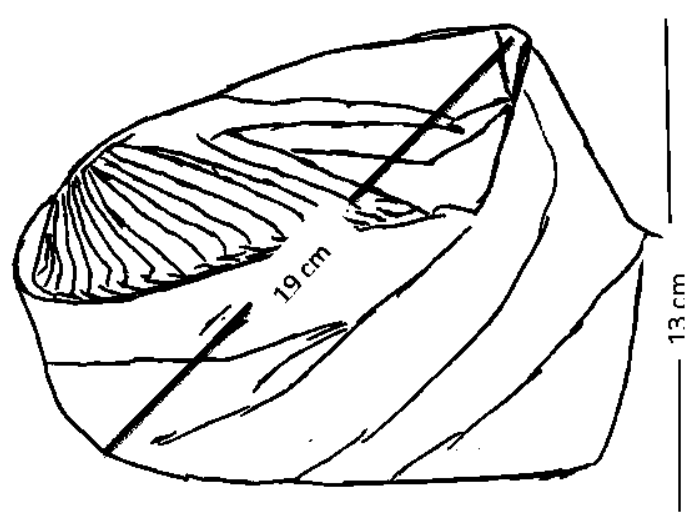

B: Turban dimensions

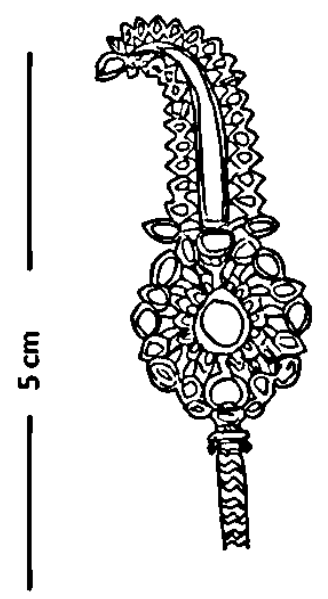

D: Precious stones dimensions

[FIGURE 19]: Dimensions of the Boxes and their Functional Relevance 


\section{MANUfacturing MATERials}

\section{Manufacturing Materials and Method}

Two materials were basically used for manufacturing the boxes, namely wood and papier-mâché. They were painted in lacquer ${ }^{25}$.

Wood: India was known for the finest types of wood, especially in Mysore, Rajasthan, and Bombay ${ }^{26}$. The Mughal rulers paid great attention to the wood in furniture. Their interest in the wood was parallel to their interest in manuscripts, jewelry, and other artifacts. It was used in the antiques, as well as Islamic and European furniture. Moreover, the Mughals used wood in making small boxes closed with silver lockers. Wooden works were made in the emperor workshops ${ }^{27}$. Mughal woods were decorated with lacquer, especially in the $10^{\text {th }} \mathrm{AH} . / 16^{\text {th }} \mathrm{AD}$. Century and flourished at the time of Akbar ${ }^{(28)}$. Lacquer is traditionally applied in certain steps. The manufacturer prepares the wooden surfaces by cleaning and polishing them. Then, some lacquer layers are applied using a hair pen or a fine piece of cloth. After that, the surface is polished with an ancient stone. The last layer is covered with burned dust to settle and protect the wooden surface against humidity that causes the degradation of wood ${ }^{29}$.

Papier-mâché: It was known in the $18^{\text {th }}$ century and continued in the $19^{\text {th }}$ century as an impact of the European arts. It was used in many artifacts and furniture. It was used instead of wood as a cheap, usable, and easy way to produce an alternative in products not prone to degradation. It was also used in keeping light products ${ }^{30}$. Papier-mâché is made by immersing paper for three days in water until becoming soft dough. Then, it is mixed with gum and some glue to become feasible and easy to configure. Molds are prepared and painted with gum ${ }^{31}$. The body of the box was molded. Then, the cover was molded. Thus, the cover was movable. Papier-mâché was covered with a layer of lacquer directly on the surface of the artifact ${ }^{32}$.

The decoration is made by painting the surface after the lacquer on wood or papiermâché using brushes. It is worth noting that brushes of different sizes and thickness were used. They were made of fine hair in the ears of bulls, donkeys, and calves, as well as fibers and cortices of certain trees. However, the best brushes were made of the hair of the tails of cats, goats, and squirrels ${ }^{33}$.

Kashmir made many artifacts decorated with lacquer, including turban boxes. From the $17^{\text {th }}$ to the $19^{\text {th }}$ centuries, India was advanced and self-sufficient in fine industries ${ }^{34}$.

\footnotetext{
${ }^{25}$ Lacquer is a paint used for hard and potentially shiny finishes. It is a red gum produced by some insects living in the East Indies. India is the main source of the production of lacquer despite being known and produced in some East Asian countries. .

${ }_{26}^{26}$ COOMARASWAMY 1923: 66-67.

${ }^{27}$ MUHAMMAD 2012: 232.

${ }^{28}$ ACRY 1993:143.PL.11.

${ }^{29}$ LOUISE, D et AL. 2019: 531-544.

${ }^{30}$ VAN \& WILLIAMS 1986: 125:143.

${ }^{31}$ AHMED 2001: 514:526.

32 LOUISE, D et AL. 2019: 537.

${ }^{33}$ LOUISE, D et AL. 2019: 537.

${ }^{34}$ DIGBY 1973: 90.
} 


\section{Hamada Thabet Mahmoud}

Moreover, making wooden boxes was a fine local industry in the royal workshops established by the Mughal-Indian emperors across the Indian sub-continent or in different regions, including the Dikkan Region.

\section{Manufacturing Materials and their Relationship to the Function of the Artifact}

Using lacquer on wood or papier-mâché was suitable for achieving the function of the turban boxes. It is known that these materials could be degraded, especially when being exposed to humidity or water that could harm the turbans kept inside. Unlike the misconception that once the wood is dried, it permanently fits use, when the wood is exposed to humidity, it experiences several problems, such as deflation, torsion, and losing features ${ }^{35}$. Because of the high value of the contents of these boxes, lacquer was used to handle external surfaces of the artifacts made of wood or papier-mâché to keep them from various factors. Lacquer is a plastic buffer and can protect surfaces and resist strong acids and alkali, water, and other fluids. Thus, the surface is easily used in cleaning. At the same time, it achieves the required shining of the artifact as a decorative facade and a background valid for the implementation of the decorations. Furthermore, papier-mâché was used in making these boxes because they were less vulnerable to collision and degradation and contained light things. Accordingly, functionality was achieved.

\section{SOCIAL CULTURE AND ITS IMPACT ON THE DECORATIONS OF TURBAN BOXES}

Most turban boxes are attributed to Northern India that included, since the time of Akbar, Kashmir, Kandahar, and Kabul ruled by one Sabah Dar ${ }^{36}$. The Mughal-Indian emperors supervised the artistic centers that were directly affiliated to the state ${ }^{37}$. After the completion of work, their notes were recorded on the products. Akbar could seize Kashmir in 1586 and seized the other parts of the north in 1593. Accordingly, Kashmir became one of the most important art centers that adopted the Mughal artistic style at the time of the Mughal-Indian emperors ${ }^{38}$.

In Northern India, there were several nationalities, including the Indo-Aryan, Turkish, Persian, and Mughal. There were several languages, e.g., Sanskrit, Urdu, and Persian spread. Moreover, there were many religions ${ }^{39}$. Thus, local cultures varied and had an impact on Islamic arts, in general, and turban boxes, in particular. Another factor that played a part was employing the Hindu artists in the ceremonies and art workshops in the era of the Mughal emperors. In the era of Hamayun, several Hindu workers were

\footnotetext{
35 REEB 1997: 5.

${ }^{36}$ Sabah Dar is the great commander of the soldiers and the appointed Sultanate in a large state of India and the deputy of the Sultan in that state. He has to command soldiers and receives large amounts of money as a way of grace. He is also given a piece of land. He stays in a large village as the head quarter of the state. There are other positions in the state, such as al-Sadr, the judge, the mufti, the legal representative, the Muhtaseb, etc

37 SIVARA 1970: 23.

38 cABD AL-RAHIM 2010: 125.

39 cABD AL-RAHIM 2010: 125.
} 
employed in the emperor's ceremony. It was reported that there was a larger assembly of about seventy painters, mostly Indians. Since the later era of Akbar, Indian artists could add a national character to the Mughal-Indian painting thanks to the traditional Indian elements they added from Kashmir, Kajrat, and Punjab ${ }^{40}$. The most significant decorations on the boxes were, as follows:

\section{Indian Deities}

Religious studies report several deities and beliefs in Indian religions that India was called the land of the gods ${ }^{(41)}$. Religions and deities differed from a region to another, even in the same region. Furthermore, it was reported that India almost knew all kinds of creeds and philosophies ${ }^{42}$

\section{Indian deities and Mughal culture}

Indian deities appeared on the applied arts during the Mughal era. The culture of rulers as well as Muslims at that time accepted the emergence of these deities especially India came under the rule of the Mughal state and thus resulted in a diversity of ruled peoples. These peoples have their own beliefs and idols that appeared on the applied arts of that period ${ }^{43}$. This is due to the policy of religious tolerance of the Mughal rulers this policy that appeared since the era of Babur and continued throughout the reign of the Mughal and Sectarian harmony was made between Hindus and Muslims ${ }^{44}$. Deities appeared on the arts as a result of religious ideas in that period, such as the divine religion that Akbar invented, as well as the spread of Sufi thought. The translation movement, especially the translation of ancient books into Persian, had a great impact on the emergence of Indian deities ${ }^{45}$. So it reflects the culture of the times and it's the influence of the Indian environment.

Animals had a special place in the embodiment of the Indian heritage because the Indians thought that the life-cycle might bring someone to another (inhuman) form after death. Thus, animals generally had a special status in the different Hindu religions ${ }^{46}$, and many Indian deities were embodied in the form of animals and human forms [FIGURE 20]. It is also possible to be these Boxes are for princes or senior statesmen the same is true for the wealthy. Additionally, these deities appeared on turban boxes:

Hanuman is a highly respected monkey among the Indians. It takes forms as big as a $\mathrm{man}^{47}$. The paintings of Hanuman resembled justice, power, and courage. Besides, Hanuman played a role in the return of Rama to his wife Sita ${ }^{48}$. The paintings of

\footnotetext{
${ }^{40}$ WELCH 1994: 9.

${ }^{41}$ SHAWKY 1984: 221.

42 cALY 2004: 128.

${ }^{43}$ 'ESAM 2002: 186.

${ }^{44}$ WILLIAM 1987: 73.

${ }^{45}$ ASGHAR 2008: 55.

46 SCHOMP 2005: 55.

${ }^{47}$ DURANT 2011: 207-208.

${ }^{48}$ SEYLLER 199: 40.
} 


\section{Hamada Thabet Mahmoud}

Hanuman appeared on the turban boxes as an influence of the local Indian culture; see the turban box made of papier-mâché in Kashmir. [FIGURE 3]

Ganesh: India and Ethiopia are the most common homes for elephants [34]. In India, elephants are almost used in wars, decorations, celebrations, hunting tigers, processions of kings, travel, and carrying heavy loads ${ }^{49}$. In the Mughal era, a place was dedicated to breeding elephants known as «Filkhaneh» and its official was called «Shahna Fil» ${ }^{50}$. Indians worshipped the elephants, as shown in Ganesh, the son of Chetta. Ganesh embodied the beast nature of the human being. At the same time, its image was taken as an enigma that protects the man against bad luck ${ }^{51}$. The Ganesh appeared on turban boxes as a cultural influence of Northern India [FIGURE 3]. It appeared in the form of an animal in the processions of knights [FIGURE 2] and individually [FIGURE 14].

Krishna: Myths reported that Krishna was a king of Northern India. He is worshipped as the eighth avatar of the god Vishnu that has 24 avatars. It has two different characters. Some folk tales depict Krishna as a cruel and tough war hero, whereas others depict it as a fun young man. In the latter position, thousands of Indian women worship it a day. It represents a cow herder and the god of fertilization among cattle herders ${ }^{52}$. Krishna was depicted on turban boxes in scenes representing celebrations and processions, as a manifestation of the Indian culture [FIGURE 2]. Krishna appeared with brown skin, indicating his birth from the sky or from the god Vishnu, and the Rasamandela dance is among the dances mentioned in ancient sources. There are many Mughal manuscripts with scenes of Krishna in manuscript. Including image of Krishna hanging the Devil «Naraka», a paper from a separate copy of Harivamsha (993-998 AH/ 1585-1590 AD).

Naga: The snake represents a special case in the Indian culture. It is the real ruler of the secret areas and indisputable water ${ }^{53}$. Because of its importance, the Indians have an annual celebration for the god Naga to which they offer milk and bananas at the entrance of its holes ${ }^{(54)}$. Indian snakes were depicted on the styles of turban boxes, such as the depictions of a box for keeping the jewel of the turban [FIGURE 16].

Animal Paintings: Several animals were painted on the applied artifacts at the time of the Mughal emperors of India. They were local animals and included foxes, rabbits, horses, and elephants ${ }^{55}$. Horses have been known in India since time immemorial. They were highly appreciated in the Mughal era, and a thief of horses was sentenced to death. They were used in wars and hunting trips. Moreover, they were painted a lot by Indian artists, especially in the Mughal era when horses appeared in several paintings of the manuscripts of the Mughal and local schools ${ }^{56}$. Several artistic themes depicted horses, such as wars, hunting, recreation, and preparation for trips or travel. Horses

\footnotetext{
${ }^{49}$ DURNT 2011: 207.

${ }^{50}$ DE LAGRAZA 2010: 36.

51 AGA- OGLU 1931:1-5.

52 NIRMALA 1995: 150.

${ }^{53}$ BRIJBHUSHAN 1979: 9.

${ }^{54}$ DURANT 2011: 208.

${ }^{55}$ IRWIN 1972: 448-463.

56DAS 1991: 20.
} 
appeared in scenes reflecting the Indian environment and culture. For instance, [FIGURE 21] shows princes and princesses riding horses in celebrations and dance settings.

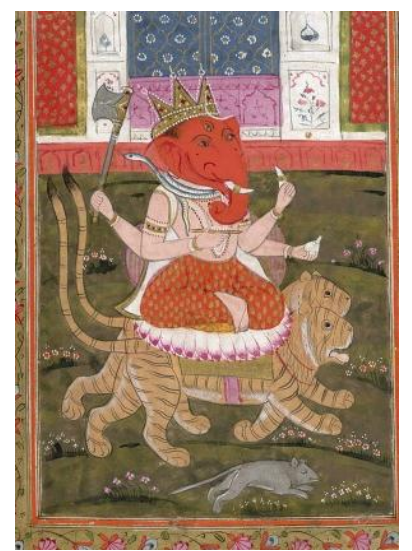

Ganesha, Ramayana , British Library, (18 AD).

(A)

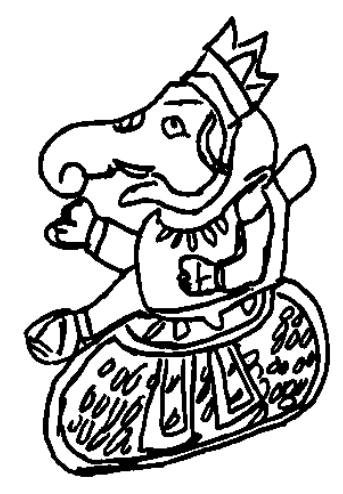

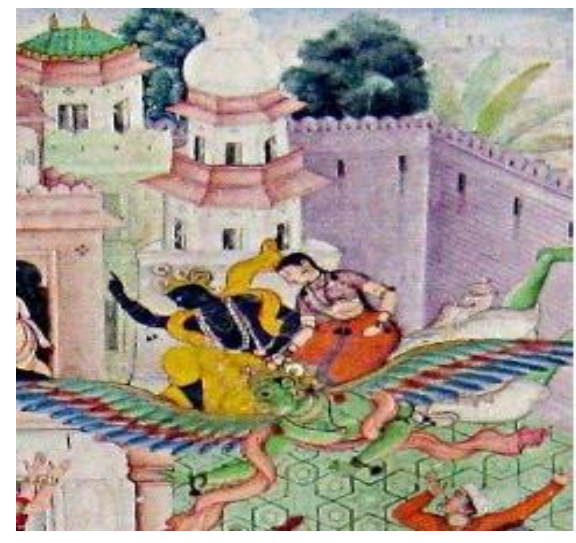

Krishna hanging the Devil «Naraka», Harivamsha (1585-1590).

Deities on painting.

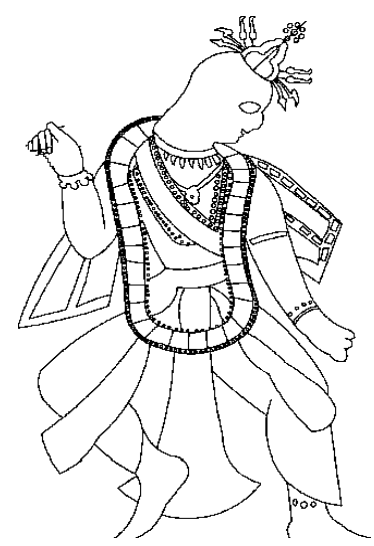

Ganesha on the turban Boxes. Krishna on the turban Boxes. ALA' 2012: PL.46

(B): Deities on the turban Boxes

[FIGURE 20]: Deities on the turban Boxes and painting 


\section{Hamada Thabet Mahmoud}
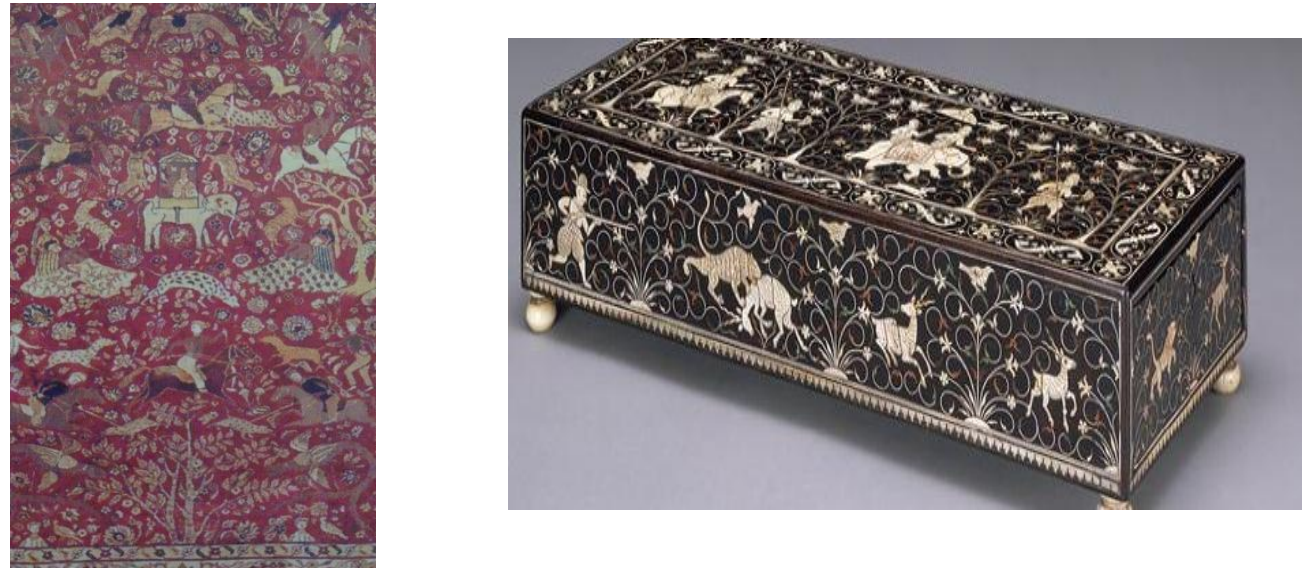

Carpet, india, $17^{\text {th }}$, Museum of Wooden Box, Indian 17, Victoria and Albert Museum Decorative Arts in Paris

(A): Animals on Mughal India
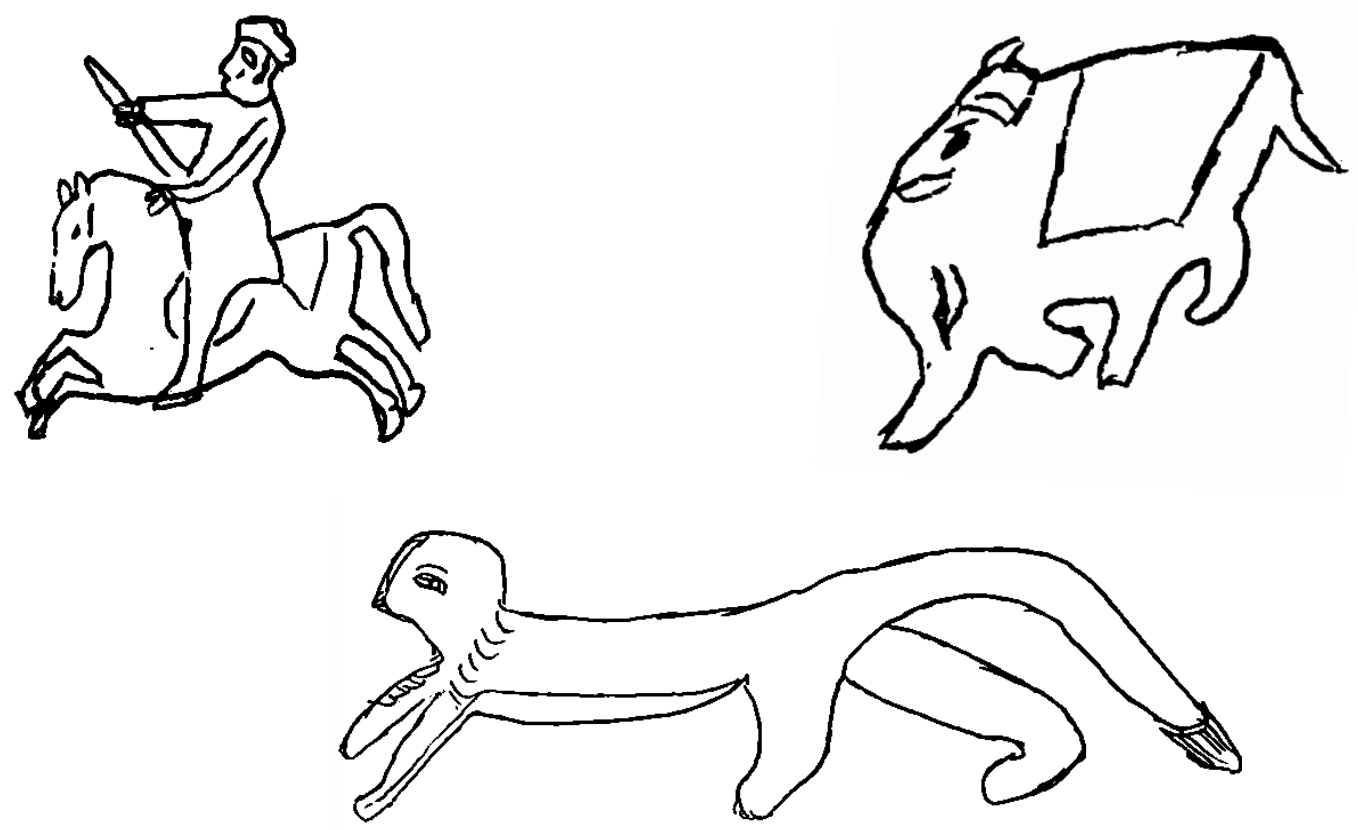

(B) Animals on the turban Boxes

[FIGURE 21]: Animals on Arts of Mughal India.

\section{Superstitious beings}

At the time of the Mughal emperors, the Indian culture, especially Northern India knew many stories and myths that were reflected in applied arts, including turban boxes.

Winged Angels: Human bodies with wings at the top of their backs appeared on the turban boxes ${ }^{57}$. They were almost yellow and were painted in three-quarter flying or standing positions, [FIGURE 15]. Their facial features were almost feminine with crowns upon their heads. They were quite similar to the paintings of winged angels in the Kashmir School in the $19^{\text {th }}$ Century as one artistic unit on the different arts, [FIGURES $22 \mathrm{a}, \mathrm{b}, 23 \mathrm{~A}$ ] 
Dragons: A dragon resembles a creeping animal with a huge long tail ${ }^{58}$. In the Kashmir School, it was portrayed in a famous scene known as «Rustam Kills the Dragon using the Sword» in a three-quarter position. Rustam wore a shirt of leopard skin, a helmet of a cheetah head, yellow pants with long red ribbons, boots, and a belt. He hanged the quiver of arrows and a sword. In front of Rustam, a big gray dragon stood on the four legs bleeding [FIGURES 22 c, d, 23 C].

Goblins: Goblins were known in the Mughal-Indian painting, especially in Northern India and Kashmir as a cultural heritage that clearly reflected the Indian environment. They were almost similar in terms of the terrible appearance with a human body, an animal head with horns, and an animal tail. Moreover, several colors were used ${ }^{59}$. [FIGURES 22 H, W, 23B] shows goblins on a box for keeping the turban's jewel.

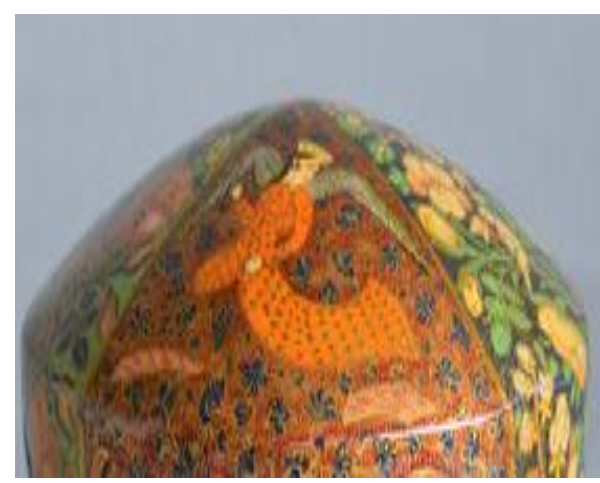

A: Decoration of Winged Angels on turban boxes

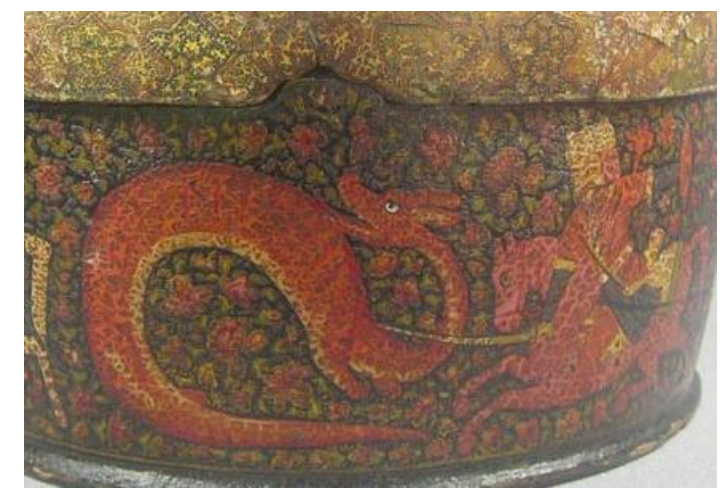

C: Decoration of Dragon ( Rustm kills the dragon) on turban boxes

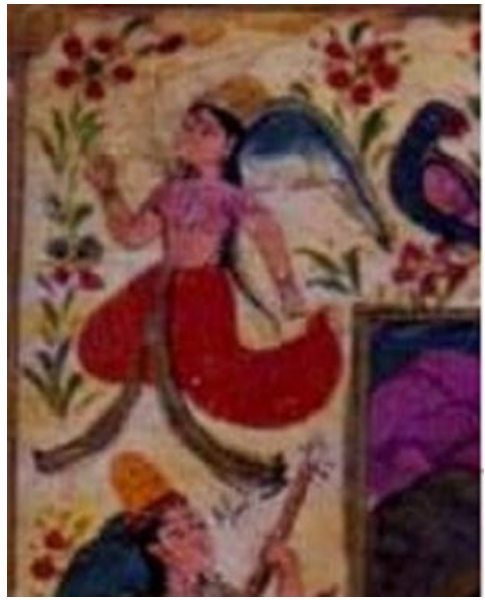

B: Decoration of Winged Angels, albustan wa alkilstan manuscript 18AD, cABD AL-RAHIM 2010: PL.10.

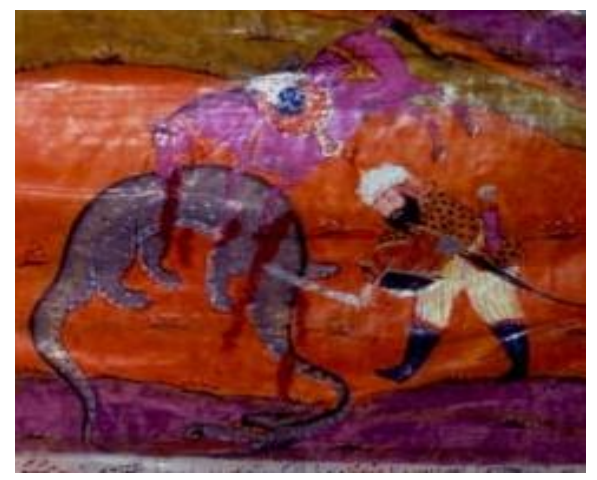

D: Decoration of Dragon ( Rustm kills the dragon), Shahnameh $18^{\text {th }}$ AD, cABD AL-RAHIM 2010: PL.60. 


\section{Hamada Thabet Mahmoud}

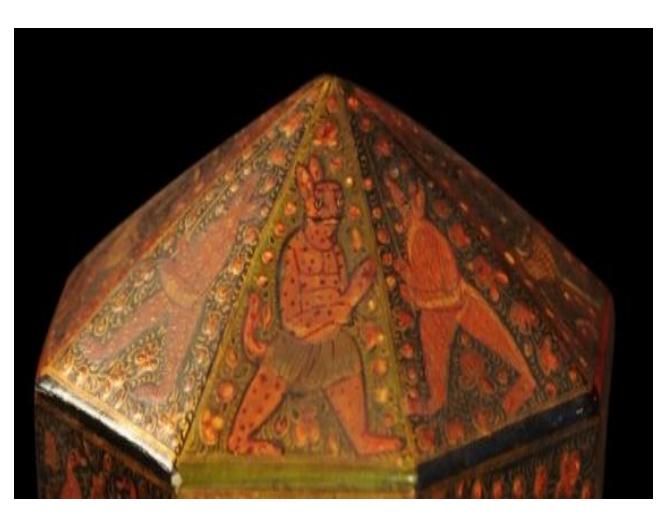

E: Decoration of Goblins on turban boxes

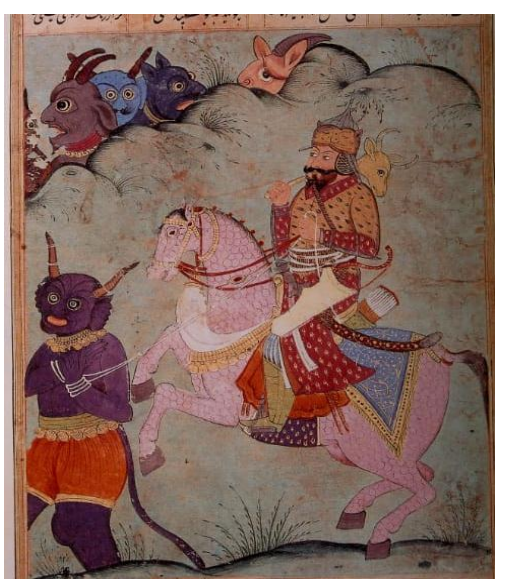

F: Decoration of Goblins, Shahnameh manuscript (1143 AH/ 1730 AD), cABD AL-RAHIM 2010: PL.51.

[FIGURE 22]: Decoration of Superstitious beings on turban boxes and Painting

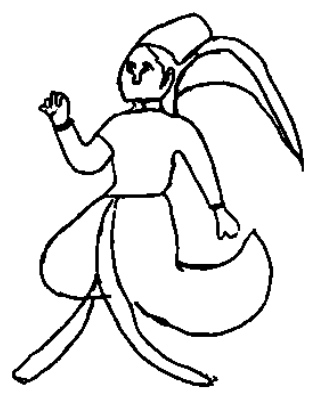

Decoration of Winged Angels on Painting

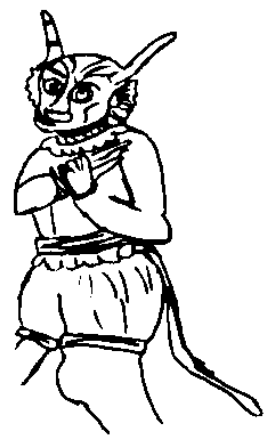

Decoration of Goblins on Painting
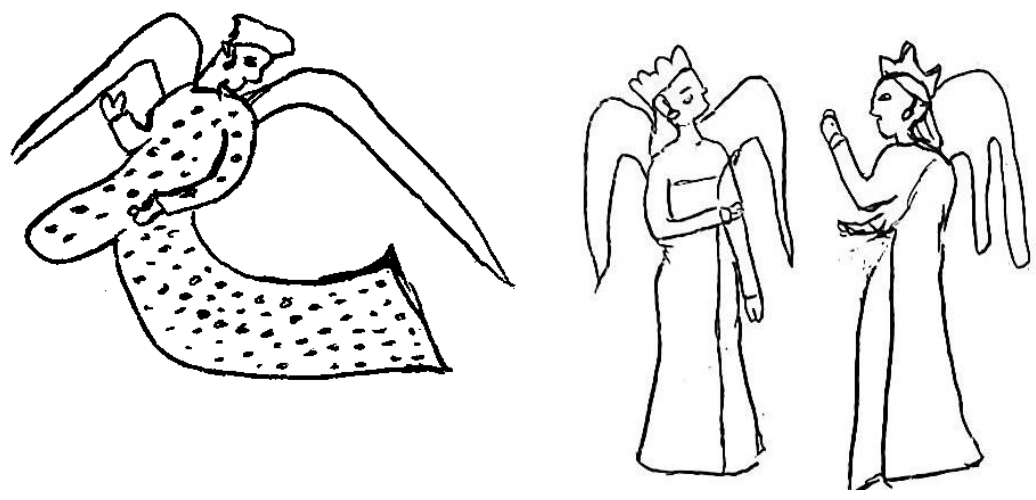

Decoration of Winged Angels on turban boxes

A: Decoration of Winged Angels
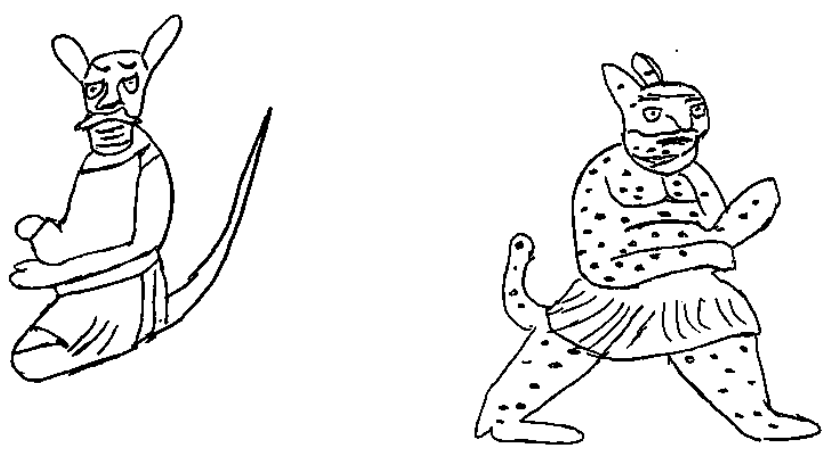

Decoration of Goblins on Turban Boxes

B: Decoration of Goblins 


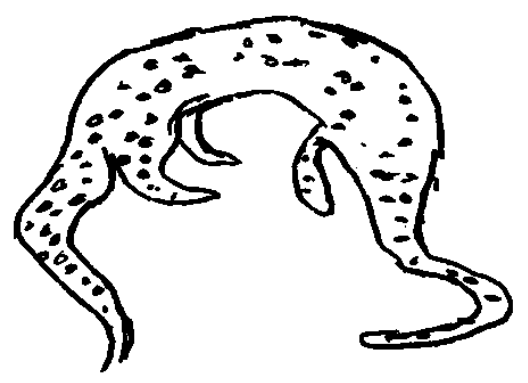

Decoration of Dragon on Painting

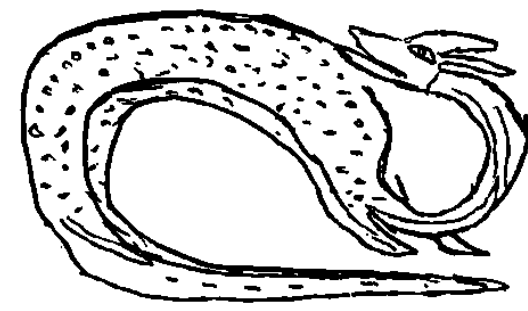

Decoration of Dragon on turban boxes

\section{C: Decoration of Dragon}

[FIGURE 23]: Decoration of Superstitious beings on turban boxes and Painting

\section{Decoration of Men and Women:}

Men and women appeared in arts, in general, and turban boxes in particular, to express the Indian society. They were of medium height with a relatively large head. Their faces were oval or square with clear eyes, arched eyebrows, and small mouths relatively. The paintings of men had black mustaches and beards, and those of women were beautiful with a black lock of hair in front of the ear in both paintings ${ }^{60}$. [FIGURE 24] shows an example of those depictions from Kashmir School on a turban box. Men were portrayed in different scenes, such as chivalry, princes in concerts, or love scenes. In contrast, women were depicted playing musical instruments, dancing, princesses and maids, or knights with a shield. [FIGURE 25].

The effect of the Indian culture was clear in the decorations of men and women on turban boxes. Men wore Indian shirts with long sleeves, Indian salwar (an item of famous Indian clothing for men), and caftans. Both men and women also wore the fayran, a famous Kashmiri outfit; a top piece of clothing almost made of wool and an opening down to the belly belt ${ }^{61}$. Jamat was a cloth that spread in the Mughal period in India. It was a long robe below the knees with long sleeves. It was often tight with a belt called Battka ${ }^{62}$. There was a long soft cloth below the knees for the women. It had almost one color and decoration in the form of a group of small flowers. Dobta (an Urdu word for a scarf) was a headwear for the women. It was a piece of cloth of three ells covering the head. Several fabrics were used for the Dobta according to the social status of women. The local culture in Northern India appeared in the musical instruments on which women played, such as the Kashmiri rebab that resembled the Iranian one with one opening and a long arm decorated with longitudinal lines ${ }^{63}$.

\footnotetext{
60сABD AL-RAHIM 2010: 137.

61 BISEAS 1985: 37.

62 BRIJBHUSHAN 1979: 11.

63cABD AL-RAHIM 2010: 137
} 


\section{Hamada Thabet Mahmoud}

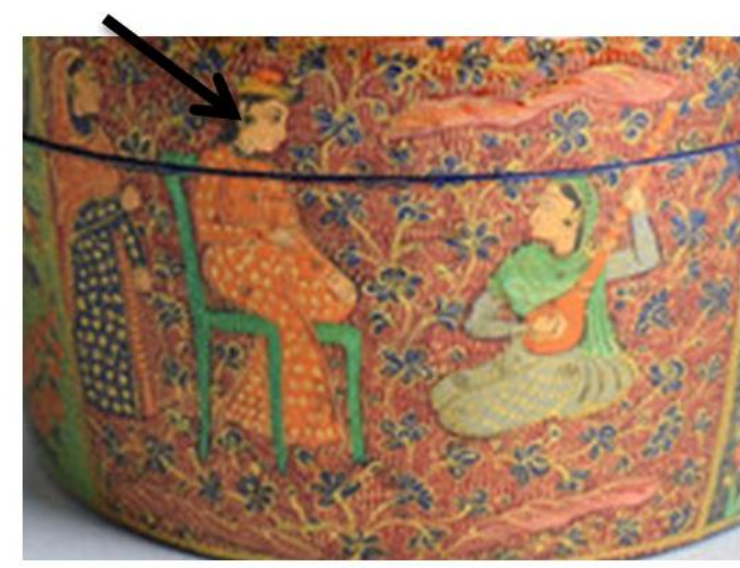

A: Decorations men and women (a lock of hair) on Turban boxes

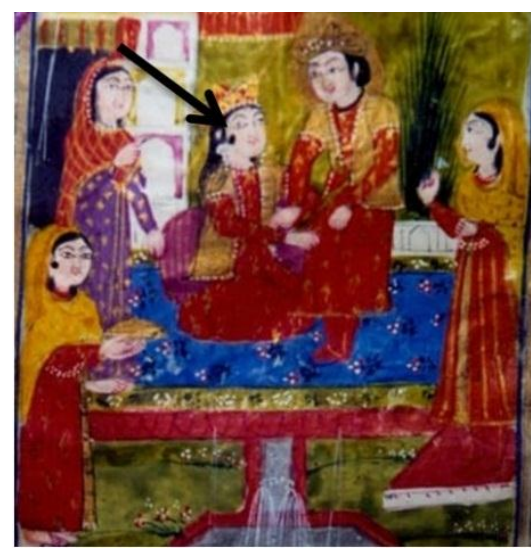

b: Decorations men and women (a lock of hair), Yusef and Zulekha manuscript, 'ABD AL-RAHIM 2010: PL.123.

[FIGURE 24]: Decoration of men and women on turban boxes and Painting

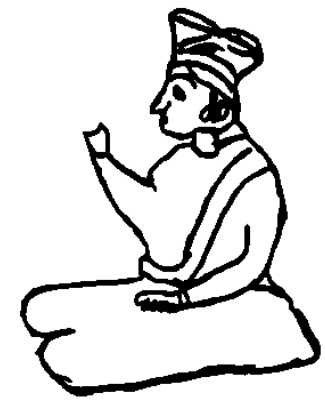

A: Humans Decorations on Turban boxes

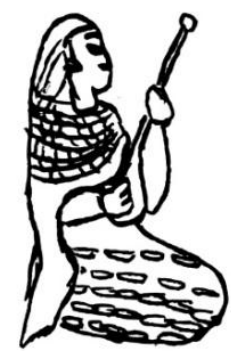

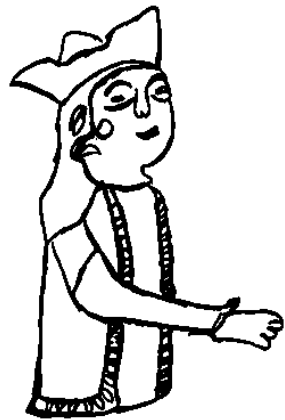

B: Humans Decorations on painting

$$
\text { C: playing musical instruments }
$$

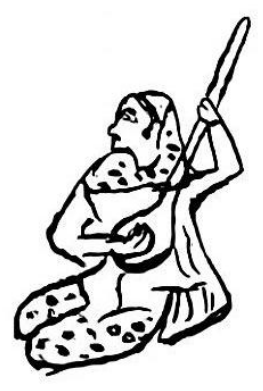

[FIGURE 25]: Decoration of Humans on turban boxes and Painting

\section{Composite Scenes:}

Combining several scenes in one was one of the most important features of Iranian painting, especially the Safavid School. This phenomenon was also known in the Mughal-Indian arts in manuscripts or scenes on applied artifacts ${ }^{64}$. Indian applied 
artifacts included scenes of the local environment in composite settings, including the turban boxes. [FIGURES 8, 9, 15).

\section{Floral Motifs:}

Floral motifs were implemented accurately and amazingly on turban boxes as a manifestation of the Mughal-Indian art, including flowers, buds, leaves, and branches ${ }^{65}$. Northern India was famous for loving flowers because of the amazing nature of their land. They used to go to foothills, gardens, and parks to enjoy flowers. They also have special customs for farming flowers. The Kashmiri cover the roofs of their houses with mud and plant Tulip that blooms in spring after rainfall, giving a beautiful image of their houses ${ }^{66}$.

It is worth noting that the visiting and settling of the Mughal emperors in Kashmir had an impact on the arts of the Mughal-Indian court. The shapes and kinds of Kashmiri flowers were a style and a basis for decoration in many arts in palaces, on textiles and carpets, etc. In 1030 AH/1620 AD, Jahangir ordered that all flowers of Kashmir and Northern India should be depicted in his paintings ${ }^{67}$.

Using flowers was reflected in applied arts, including turban boxes. For instance, the tulip was used in the artistic configurations of the background as decorative themes or as independent floral motifs. Because Carnation could be found in India throughout the year, Kashmiri farmers were interested in it ${ }^{68}$. Saffron, leaves, and cypress were also depicted. The cypress of Kashmir has a dark color. Additionally, the cypress represents the traditional tree in the gardens of Kashmir. Thus, it was represented alone with a traditional pyramid-like top and leaves as an equilateral triangle. Cypress also appeared on the Mughal tombs because of its symbolism in the Persian literature. Furthermore, blooming trees were known in the Mughal-Indian arts [FIGURE 26].
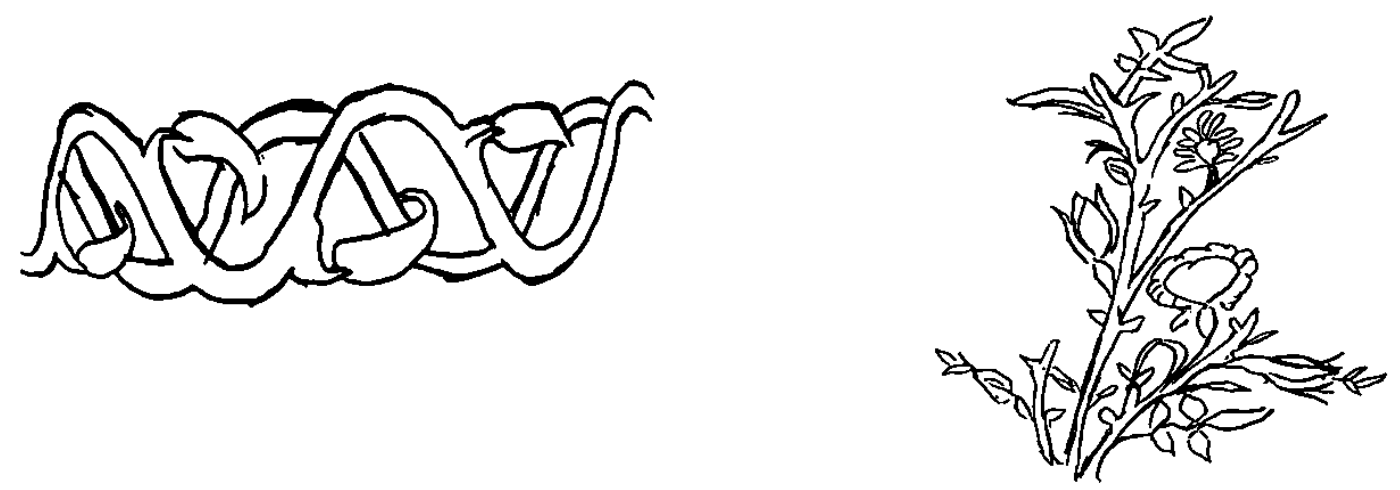

[FIGURE 26]:Floral motifs on turban boxes.

\footnotetext{
65 GOEL 2007: 243.

66 cABD AL-RAHIM 2010: 157.

67 GOEL: 243.

68 KHALIFA 1998: 372.
} 


\section{Hamada Thabet Mahmoud}

\section{Geometric Decorations:}

Geometric decorations was one of the fields that received due attention from the artists of the Mughal-Indian era, especially in buildings and carpets. Geometric configurations or cartouches decorated the space of the artifact and contained floral motifs. As a part of the Mughal arts, they appeared on turban boxes ${ }^{69}$, [FIGURE 4]. illustrates the star shapes in the background [FIGURE 11]..

\section{FUNCTION AND DESIGN OF THE ARTIFACT AND ITS RELATIONSHIP TO THE DECORATIVE THEMES:}

\section{Decorative Themes and Relationship to the Function of the Artifact:}

Turban boxes were decorated with several themes, including animals, human beings, as well as floral motifs, and geometric decorations. A question may arise: Why were turbans boxes rich in decorations? Was there a relationship between these decorations and the function of the artifact? The decorations on the boxes included different scenes representing the local style largely, such as the meetings of princes and councils of princesses. Furthermore, animal paintings, superstitious beings, and floral motifs expressed the local environment largely. Thus, there is a relationship between the local environment and the turban boxes of the Mughal emperors or local princes. In short, the Indian turban represents the local environment and customs. It was decorated with local scenes.

\section{Design of the Artifact and its Impact on Decorations:}

The decorations differed from inside and outside the turban boxes. From Outside:

The body of the boxes was circular, and the artist distributed decorations on both the body and the cover. That is, scenes encircle the body and continue upon the cover. Thus, the body and the cover were one part on one background for implementing decorations [FIGURES 2, 3, 5, 10]. Concerning the geometric decorations, rectangular cartouches were on the body and continued on the cover as one background [FIGURE 4]. In the polygon boxes, the artist distributed the decorations on the sides of the body and the cover. Each geometric part had an independent configuration of one scene, [FIGURES 11, 12, 13].

Inside the box: Internal decorations were simple and were not affected by the design of the body, whether circular or polygon. They were almost floral motifs in geometric decorations, [FIGURE 11]. 


\section{IMPACT OF ARCHITECTURAL STRUCTURES}

Mughal-Indian arts are characterized by representing various forms of architecture and applied arts. In the Mughal-Indian era, painting linked complete cohesion and unity ${ }^{70}$. Therefore, artists, especially in India, were influenced by the buildings in forming artifacts, especially the architectural elements ${ }^{71}$. These impacts were reflected on these boxes. Thus, the cover of the box had the design of Indian domes, such as those of the Taj Mahal mausoleum in Agra ${ }^{72}$. The general design of the cover was affected by the onion-like mausoleum domes. In the Mughal era, domes were cylindrical. Some domes moved from the square to the circular shape by putting squinches in the sides of the square upon which the circular shape was formed. In addition to the big dome, there were small or medium domes. The big dome was established on the mihrab of the mosque, including the dome of the Islamic Center in Delhi, India. Moreover, some boxes were affected by the dome of Atqa Khan Mausoleum ${ }^{73}$ in Delhi 1562-1566, [FIGURE 27].
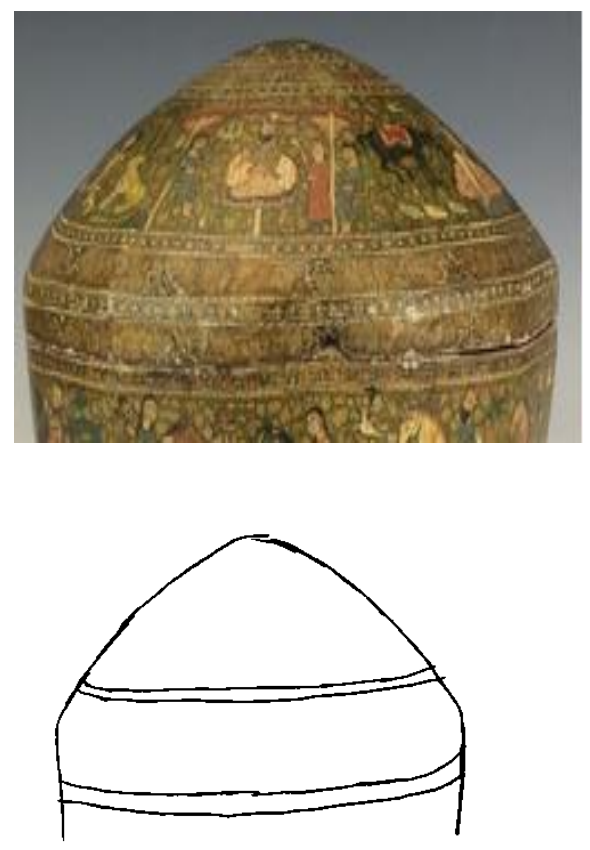

A: Turban Box Cover
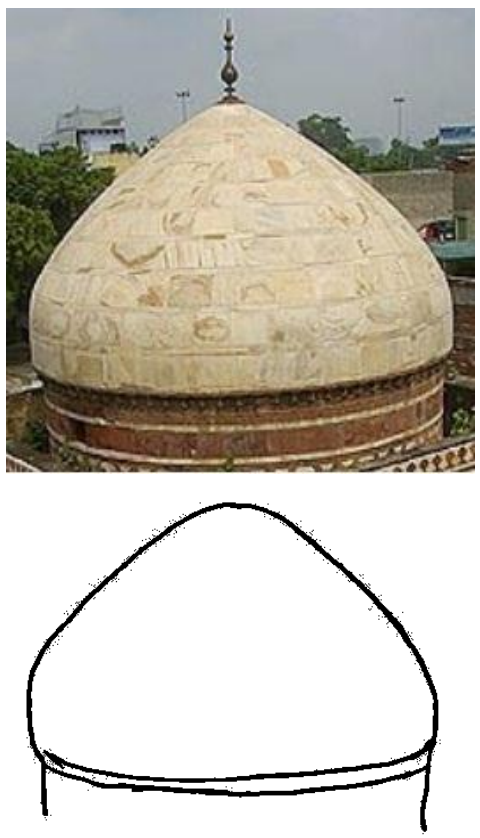

B: Mausoleum of Atqa Khan, Delhi 1562-1566.

[FIGURE 27]: Impact of Buildings on the Design of Turban Boxes.

70HUSSEIN 1989: 314-315.

71 YASIN 2014: 146-166.

72 KOCH 2005:.128-149.

73 Shams-Elden Muhammad Atjah Khan (Atqa Khan) (died on May 15, 1562) is also known as Khan Klan Shamsoud-Elden Muhammad Khan Atjah Khan. He held important positions in the Mughal court. 


\section{Hamada Thabet Mahmoud}

\section{CONCLUSION}

Artifacts and fine industries flourished in the era of Mughal- Indian emperors, as shown in Turban boxes that were known as juaba distar; a Persian phrase for boxes used to keep turbans. The Mughals, including emperors or princes, paid great attention to turban boxes because of the importance of the turban itself that reflected the position of its user, especially at the time of Babur. At the time of Hamayun, the turban was used to climb high places by connecting its parts. The turban was decorated with jewelry and gemstones more than ever, especially at the time of Jahangir. The feather and stick on which the jewel was fixed were made of gold. Therefore, small boxes with the same design as the turban boxes were introduced. The boxes generally comprised two parts: The body and the cover. There were several artistic styles, such as the box of a circular body and a semi-spherical dome, and the style of a circular body and onion-like dome. The third style comprised a small base, a wider upper part, and a convex dome. The fourth style was a circular decagon body and a polygon dome, whereas the fifth style had an octagonal body. The small boxes with the same design were almost used for keeping the turban's accessories, including the diamond and the golden stick. The dimensions of the box were suitable for the function of keeping the turban, and the cover ensured protection. Wood and papier-mâché were used for manufacturing the boxes, but they were treated with a lacquer to have isolated surfaces in order not to harm the turban and the accessories. The decorations implemented on the boxes reflected the culture of Northern India, especially Kashmir. Thus, these decorations included the deities of Hanoman, Kreshna, and Janetha, as well as animals, e.g., horses, foxes, and elephants. The paintings of the mythical beings representing the Indian environment, e.g., dragons, angels, and goblins resembled those of the manuscripts of Kashmir school at the time. Additionally, the paintings of men and women expressed strongly the Indian environment in terms of customs, facial features, or some characteristics of the paintings of Kashmir school, including the lock of hair hanging behind the ear. The floral motifs stressed the impact of the local environment, including flowers and trees in Northern India, such as Tulips and cypress trees. The general design of the distribution of decorations on the box achieved a balance between the body and the cover. The design of the boxes was affected largely in the buildings of India, including Indian and onion-like domes.

\section{HOW TO CITE}

Thabet, H., «Indian Mughal Turban Boxes As Cultural Indicators Civilizational and Artistic Study» Journal of the General Union of Arab Archaeologists, vol. 6/2, 2021. Doi: 10.21608/JGUAA2.2021.55863.1048. htm00@fayoum.edu.eg 


\section{BIBLIOGRAPHY}

CABD EL-RAHIM, A.: «mādrāsat kashmīr fī altāsūir» (in Arabic= Kashmir School in the Paintings of Islamic Manuscripts (10-13 ${ }^{\text {th }} \mathrm{AH} / 16-19^{\text {th }} \mathrm{AD}$, PhD thesis, Cairo University, 2010.

AgA-OGLU, M.: «A Fragment of a Rare Indian Carpet», Bulletin of the Detroit Institute of Arts of the City of Detroit 13/ 1, 1931, 1-5.

AHMED, R.: "Altūhāf alīranīa almūzakhrāfa bīllaqīa fī tūa' magmū'a rīta 'abasī» (in Arabic= Iranian Artifacts Decorated with Lacquer in the Light of a New Collection at Reza Abbasi Museum), PhD thesis, Cairo University, 2001.

Al-JAHIZ, A.: Albaīan wa altabīn (in Arabic= Eloquence and Exposition), Cairo (Alkhanjy Bookstore), 1998.

Almalouf, A.: Almū'ajaìm al 'arabī līasma' almalabīs (in Arabic= Arabic Lexicon of the Names of Clothes), Cairo (Dar-Alafak Stores), 2002.

AL-QALQASHANDI, A.: Sūbah ala 'asha fì sinna't alainsha (in Arabic= Daybreak for the Night-Blind), Cairo (Zakaher Series), 1922.

ALA', M.: «altūhaf alkhashabīa fī alhīand mūndh achad aldawla almaghūlīa wa hata nīhaīat alqarn 13AH/ 19AD», (in Arabic= Wooden Artifacts in India from the time of the Mughal Empire until the end of the 13th Century AH / 19AD), Ma thesis, Cairo University, 2012.

cAly, A.: Dīrāsat fì aladīan alwathanīa alqadima (in Arabic= Studies in Ancient Pagan Religions), $1^{\text {st }}$ ed., Cairo (Dar Alafaq), 2004.

AsGHAR, A.: Sufism and Inter-Religious Understanding, Delhi (Hope India), 2008.

BISWAS, A.: Indian Costumes, India (Ministry of Information \& Broadcasting), 1985.

BRIJBHUSHAN, J.: The World of Indian Miniatures, New York (Harper \& Row), 1979.

CARY, S., Art and Culture 1300-1900, New York (The Metropolitan Museum of Art), 1993.

COOMARASWAMY, A.: «Catalogue of Indian Art», Museum of Fine Arts Bulletin 21/ 127, 1923, 66-67.

DAS A.: Mughal Masters, India (Further Studies, Marg Publications), 1991.

DE LAGRAZA, A.: Mughal at War: Babur, Akbar and the Indian Military Revolution, 1500-1605, USA (The Ohio State University), 2010.

DigBY, S.: «A Corpus of 'Mughal' Glass», Bulletin of the School of Oriental and African Studies 36/ 1, 1973, 8869.

DURANT, W.: Qasiat alh ätara (in Arabic= The Story of Civilization: India and Her Neighbors, the Far East), Trans. Z. NAGUIB and M. BADRAN, Cairo (General Egyptian Book Organization), 2011.

EL-BīRūNī , A.: Tarīkh alhīnd (in Arabic= History of India), Cairo (the Anglo-Egyptian Bookstore), 1990.

E'SAM ALDIN 'ABA ALRAŪ'F.: bilan alhind fì al 'asr alislamī mūndh fagar alisalm wa hata altaqsim (in Arabic= The countries of India in the Islamic era from the dawn of Islam until partition), Cairo (Dar alfak ār), 2002.

GoEL, N.: Birds and Animals in Indian Art - The Mughal Artist as a Naturalist, India (Exotic India Art), 2007.

GoITEIN, S.: A Mediterranean Society: The Jewish Communities of the Arab World as Portrayed in the Documents of the Cairo Geniza, California (University of California Press), 1983.

HusseIN, M.: «Indian Architecture through Islamic Paintings», Journal of the Faculty of Arts 4, 1989, 314315.

IBRAHIM, M.: Tatūr almalabīs fì alm alügtamū 'a almāsrī (in Arabic= The Development of Clothes in the Egyptian Society from the Islamic Conquest to the Late Fatimid Era), Cairo (Madbouly Books), 2007.

IBRAHIM, R.: Almū 'ajaìm al 'arabì lìasma' almalabīs (in Arabic= Arabic Lexicon of the Names of Clothes), Cairo (Dar-Alafak Stores), 2002.

IRWIN, J.: «Art and the East India Trade», Journal of the Royal Society of Arts 120/ 5191, 1972, 448-463.

JACKSON, W.: History of India, London (Thigrollir Society), 1906.

JAFFAR, S.: The Mughal Empire From Babar to Urangzebp, Peshawar (S. Muhammad Sadiq Khan Publisher), 1936.

KAMADA, Y.: «Flowers on Floats: The Production, Circulation, and Reception of Early Modern Indian Carpets», PhD thesis, New York University, 2011.

KASRATY, S.: Qamūs fārsì 'arabī (in Arabic= Persian-Arabic Dictionary), Beirut (Arab Encyclopedia House), 2014.

KHALIFA, R.: Tūhāf mā'adanīa mīn hūdarabad (in Arabic=Metal Artifacts from Hyderabad), Cairo (Monuments in the East Muslim World), 1998.

KOCH, E.: «the Taj Mahal: Architecture, Symbolism, and Urban Significance», Muqarnas 22, 2005, 128-149. 


\section{Hamada Thabet Mahmoud}

KoSSAK, S.: Indian court Painting 16 $6^{\text {th }}$ 19 $9^{\text {th }}$ Century, New York (The Metropolitan Museum of Art), 1997

Louise, D., Yvonne, J., Delphine, S., Vincent, C., Charles, I., Emile, V., Wim, F., Frédéric, L. and STEVEN, S.: «Black Lacquered Papier-mâché and Turned Wooden Furniture: Unravelling the Art History, Technology and Chemistry of the 19th-Century Japanning Industry», Studies in Conversation 64, 2019, 531-544.

Michell, G.: The Majesty of Mughal Decoration "the Art and Architecture of Islamic India", London (Thames \& Hudson), 2007.

MiCHAEL B.: akbar's india :art from the mughal city of victory, Asia Society, 1985.

MuHAMmAD, A.: «Alūhaf alkhashabīa fì al'asar almagūlī» (in Arabic= Wooden Artifacts in India from the Mughal State to the Late 13 H/19 G Century, MA thesis, Cairo University, 2012.

MuHAMmAD, A.: «Madrāsāt aldīkn fī altāsūr» (in Arabic=The Dakkan School of Islamic Painting (8951098H/1490-1687AD), PhD thesis, Ain Shams University, 2009.

NiRMALA, S.: «A Critical Study of Ragamala Paintings of Gujarat, Rajsthan and Central India», Ma Thesis, Gujarat University, 1995.

Otто-KuRZ, A.: «Volume of Mughal Drawings and Miniatures», Journal of the Warburg and Courtauld Institutes 30, 1967, 251-271.

PoojA, C., «A Study of Mughal Imperial Costumes and Designs during $16^{\text {th }}$ and $17^{\text {th }}$ Century», PhD thesis, Aligarh Muslim University, 2016.

PRISCILlA, P.: «Persian Artists in Mughal India: Influences and Transformations», Muqarnas 4, 1987, 166181.

RASHEED, S.: Almalabīs al'arabī wa tatūarha fì al'aūsūr alaslamūa (in Arabic= Arab Clothes and their Development over the Islamic Eras), Cairo (Technical Institutes for Publishing), 1980.

REEB, J.: Drying Wood, USA (University of Kentucky, 1997.

RENHAR, D.: Almū 'ajaìm almūfasal biasma' al 'arabīb (in Arabic= Detailed Lexicon of the Names of Clothes among the Arabs), Baghdad (Lisan Alarab), 1971.

ROBINSON. B. W.: «Qajar Lacurer, Muqarns», №. 6, 1989, 130- 146.

RosenZweIG, D.: Stalking the Persian Dragon: Chinese Prototypes for the Miniature Representations, Germany (Kunst Des Orients), 1979.

SCHOMP, V.: Ancient India, New York (BenchMark), 2005.

SEYLLER, J.: «Workshop and Patron in Mughal India: The Freer Rāmāyaṇa and Other Illustrated Manuscripts of ‘Abd al-Rahīm», Artibus Asiae 42, 1992, 1-25.

SHARMA, S.: Mughal Empire in India [1526-1761], Bombay (Jkarnatak Printing Press), 1934.

SHAWKY, M.: "Mīn almīthūlūgīa alhīndia (in Arabic= From Indian Mythology)», Journal of Folklore Heritage 15/ 12, 1984, 221.

SIVARA, C.: India "The Land and People", India (Indian Painting, National Book Trusi), 1970.

SWARUP, S.: Mughal Art, a Study in Handicraft, Delhi (Agamkala Prakashan), 1996.

VAN, D. \& Williams, D.: The History, Technology, and Care of Papier-Mache, Chicago (American Institute for Conservation), 1986.

Welch, S.: Persian and Mughal Miniatures, the Life and Times of Muhammad - Zaman, India (Farhang-Sara Publications), 1994.

WILLIAM, W.: Rulers of India Akbar and the Rise of Mughal Empire, USA (Clarendon Press), 1899.

YASIN, A., «Asar almonshata almamaria fi tashkil altuhaf altatbikia» (in Arabic= Impact of Buildings in the Formation and Decoration of Islamic Applied Arts in the 2-8 H/8-14G. Centuries), Almushka 23, 2014, 146-166. 


\title{
صناديق حفظ العمامة في العصر المغولي الهندية كمؤثرات ثقافية \\ دراسة حضارية فنية
}

\section{حمادة ثابت محمود}

أستاذ الآثار الاسلامية المساعد- كلية الآثار - جامعة الفيوم

\begin{abstract}
الملخص
تعبر التحف التطبيقية في عصر أباطرة مغول الهند عن حضارة المغول وإبداعتهم، وتعتبر صناديق حفظ العمامات مثالا رائعا لتلك التحف التي تعبر عن حضارة المغول، وتهدف الورقة البحثية لدراسة فنية لهذه الصناديق وكذلك ومسمي جعبة دستار وعلاقة المسمى بأداء الوظيفة التي من أجلها صنعت هذه الصناديق، ولقد كان لفلسة المغول بالهند سواء الأباطرة والأمراء في الاهتمام بالعمامة ومكانتها لديهم دور كبير في ظهور صنادي باديق لادئ مخصصة للعمامة، وكانت العمامات تزين بالأحجار الكريمة والجواهر الغالية الامر الذي أدي أيضا إلى ظهور هذه الصناديق، وتعدد طرز صناديق واديق حفظ العمامات في

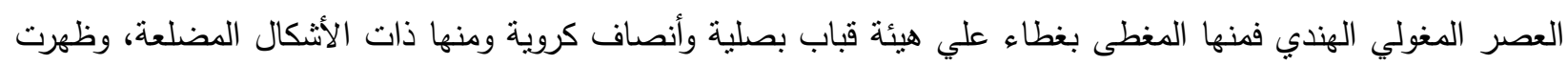
التأثيرات البيئية بشكل كبير على زخارف هذه الصناديق وكان الزخارف مرنبطة بشكل كبير بثقافة الأقاليم الهندية التي أنتجت

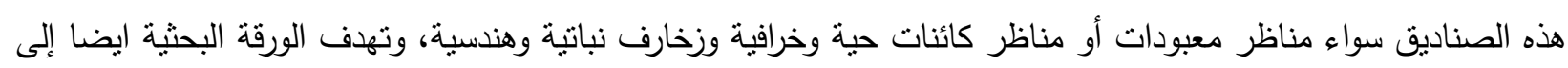

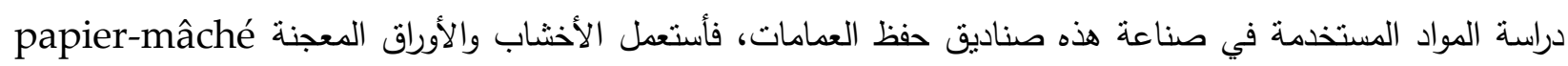
كمواد أساسية في صناعة صناديق حفظ العمامات بعد أن تتم معالجتها لتصبح صالحة لأداء وظيفة الصندوق دون الحاق

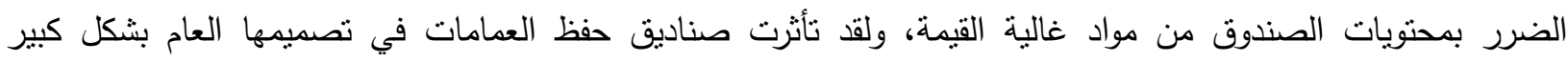
بالمنشآت المعمارية كتأثنر من العمارة المغولية الهندية المعاصرة.
\end{abstract}

الكلمات الادالة: صندوق، عمامة، خشب، لاكيه، مغول، هند، احجار كريمة. 